\title{
Labour mobility as an adjustment mechanism to asymmetric shocks in Europe: evidence from the Czech Republic, Hungary, Poland and Slovakia
}

\author{
Dennis Nchor ${ }^{*}$ (1)
}

\begin{abstract}
This paper assesses the nature and correlation of shocks in Visegrad countries and investigates the role of labour mobility in the process of adjustment to the effects of asymmetric shocks. Structural vector autoregression (SVAR) models are employed to assess the nature and correlation of shocks while dynamic cointegrated panel autoregressive distributed lag (ARDL) models are used to determine the role of labour mobility in the adjustment process. The dataset for the SVAR models is quarterly time series and covers the period 2000-2020. The dataset for the cointegrated panel ARDL models is annual and covers the period 2000-2019. The results show more asymmetries in external supply, domestic supply, demand and monetary shocks before the financial crisis. The findings also show that more symmetries occurred in Visegrad countries after the financial crisis in relation to external and domestic supply shocks. Asymmetries persisted with regard to demand and monetary shocks after the financial crisis. With labour mobility as an adjustment mechanism to asymmetric shocks, the paper finds that the capacity of labour mobility is very low. The percentage of net migration in the total population is less than $1 \%$ in the four countries compared to $15 \%$ in the United States. The size of the adjustment coefficients shows that it takes 3-5 years for countries to adjust to asymmetric shocks through labour mobility.
\end{abstract}

Keywords: Demand shocks, Supply shocks, Symmetry, Asymmetry, Labour mobility

JEL codes: F15, F41, J01, J08, J61

\section{Introduction}

This paper uses the approach of Blanchard and Quah (1989) and Bayoumi and Eichengreen (1993, 2017) to assess the nature, size and correlation of shocks in Visegrad countries for the period 2000-2020. The paper also investigates the role of labour mobility as an adjustment mechanism to asymmetric shocks. Economic shocks are defined simply as unexpected events that have either a positive or a negative impact on macroeconomic variables in the economy. These shocks are frequently beyond

*Correspondence: dennis.nchor@mendelu.cz

Mendelova univerzita v Brne, Brno, Czech Republic the scope of normal economic transactions. They cause recessions and business cycles in countries. Shocks can be symmetric or asymmetric. They are asymmetric when they affect countries in a region differently. Symmetric shocks occur when the effect of an unexpected event is uniform. This paper focuses on four types of shocks: external supply shocks, domestic supply shocks, domestic demand shocks, and monetary shocks. The study is based on the optimum currency area theory developed by Mundell (1961) and elaborated by McKinnon (1963) and Kenen (1969), in which mobility of labour and other factors of production are considered as the main conditions for smooth adjustment to asymmetric shocks. This theory was further elaborated by De Grauwe (2005), 
Krugman (1993) and Frankel and Rose (1996) with a focus on labour and factor mobility, openness and intraregional trade, and symmetric macroeconomic shocks across countries. The theory postulates that balancing the costs and benefits of regional economic integration depends largely on the synchronisation of shocks that occur in the region. In other words, if shocks are distributed symmetrically across countries of a region, the shocks are correlated, and therefore a single policy response is sufficient to counteract the negative effects across the countries.

Visegrad is a sub-regional bloc in the European Union (EU) consisting of four countries: the Czech Republic (Czechia), Hungary, Poland, and Slovakia. The countries are heterogeneous with different economic structures. For instance, the structure of production and the level of income per capita vary across these countries even though there is a degree of convergence. The presence of a certain degree of heterogeneity makes the region vulnerable to shocks. The four countries joined the EU in 2004, and of the four, only Slovakia joined the Economic and Monetary Union. Therefore, the Czech Republic, Hungary and Poland still maintain national currencies while Slovakia has replaced the national monetary policy with the common and independent policy managed by the European Central Bank. The implication of this is that the exchange rate, which is used frequently as an adjustment mechanism in the face of asymmetric shocks in countries, cannot be used in Slovakia but can be used in the other three countries. In the event of shocks, several options are available for countries to adjust their economies to recovery. This study focuses on labour mobility across the region since the countries are highly integrated in terms of trade openness and interregional trade.

This paper focuses on the role of labour mobility as an adjustment mechanism in the Visegrad region, which has been emphasised as one of the methods that counteracts the effects of asymmetric shocks. As it is difficult to measure labour mobility, the paper uses migration as a proxy, which is also used in the studies conducted by Arpaia et al. (2016), Dao et al. (2014) and Beyer and Smets (2015). Globalisation has accelerated the movement of labour and capital as well as goods and services across countries. Moreover, it has become easier to travel and work in other countries. Consequently, international labour mobility has increased significantly and has become a topic of growing policy importance. Piracha and Vickerman (2002) found that labour mobility in Europe as a percentage of the total population was lower than that in the United States (US). Martin and Taylor (1996) found that there was lower migration among European countries than expected. Obstfeld and Peri (1998) obtained similar results and concluded that labour mobility across European countries was lower than that within countries. Similarly, De Grauwe and Vanhaverbeke (1991) investigated regional and national labour mobility across several Western European countries and found that the yearly flow of migrants among the investigated countries was less when compared to interregional migration. The information above shows that labour mobility in Visegrad countries is low, implying the low capacity of labour mobility as an adjustment mechanism. However, as concluded by Puhani (1999), if the lack of economic incentives to migrate is the cause of the low labour mobility, the conclusion about labour mobility having low capacity to counteract the effects of asymmetric shocks is wrong.

A large body of literature on symmetric and asymmetric shocks in Europe focuses on Western European countries. The case of Visegrad as a regional economic bloc is rarely studied. This study therefore seeks to fill this gap. The aim of the paper is twofold. First, the paper applies SVAR models to determine the nature and correlation of shocks across the Czech Republic, Hungary, Poland and Slovakia. Second, the paper uses cointegrated panel ARDL models to assess the role of labour mobility in counteracting the impact of asymmetric shocks across the region. The paper makes unique contributions to theory and development in that rather than using the conventional two-variable modelling approach consisting of only supply and demand shocks, the paper uses a four-variable SVAR model to capture the correlation of external shocks including the global financial crisis and the correlation of domestic monetary shocks among the countries, which has been given minimal attention in previous research. The other contribution of the paper is the use of cointegrated panel ARDL models to assess the impact of migration and technological progress on employment during periods of asymmetric shocks.

The structure of the paper is as follows. The first chapter introduces the concept of macroeconomic shocks, labour mobility and its related terms. It also provides a brief overview of the motivation for and contribution of the paper. The second chapter reviews the literature. The third chapter outlines the methodology used in the study. The fourth chapter presents and discusses the results. The fifth chapter presents the conclusions.

\section{Literature review}

Visegrad was created in 1991 to promote cooperation initially among three states: Czechoslovakia, Hungary, and Poland. In 1993, Slovakia separated from the Czech Republic, thus making it a group of four countries, the Czech Republic, Hungary, Poland and Slovakia. The initial goal of the group was to promote these states as candidates for membership of the EU and the North Atlantic 
Treaty Organization (NATO). They were accepted into NATO in 1999 and into the EU in 2004. Beyond these goals, the group has continued to foster regional and economic cooperation. Slovakia was the first Visegrad country to join the Eurozone in 2009. The Eurozone is a monetary union of countries in the EU that adopt the euro as their currency. By joining the Eurozone, Slovakia became more tied to the EU core than the other three Visegrad countries. The four countries follow their own individual interests with regard to the Eurozone and the common currency. The Czech Republic, Hungary and Poland have not joined the Eurozone.

All the Visegrad countries have a high export dependency ratio, which, according to data from Eurostat (2020), has increased over the years. Slovakia has the highest share of exports in gross domestic product (GDP) with $90 \%$, followed by Hungary with $80 \%$, the Czech Republic with $75 \%$ and Poland with $50 \%$. Real GDP per capita in all the countries is rising. The highest real GDP per capita is in the Czech Republic. Inflation is declining in all the countries and converging. Poland has the lowest inflation rate. Similarly, unemployment is declining and converging in all the countries. The lowest level of unemployment is in the Czech Republic. The Czech Republic, Hungary and Slovakia have positive net migration while Poland has negative net migration, implying that there are more immigrants than emigrants in the Czech Republic, Hungary and Slovakia and the opposite in Poland. The employment rate of foreign workers is high in all the Visegrad countries, with the Czech Republic having the highest rate of employment of both EU and non-EU workers. The percentage of immigrants is less than $1 \%$. The highest percentage is in the Czech Republic, followed by Hungary and Poland. Slovakia has the lowest immigrants to population ratio. Its emigration to population ratio increased after the financial crisis. Poland and Slovakia overtook the Czech Republic as the countries with the highest emigration to population ratio after the crisis. The percentage of net migration in the Visegrad region is too low, however, at less than $1 \%$.

Movement of workers from one EU member country to another has become an important and necessary alternative adjustment mechanism for the EU countries (see European Commission 2011). Labour mobility and migration are complex phenomena; however, they are used interchangeably following the approach of the European Commission (European Commission 2011). A study conducted by Arpaia et al. (2016) showed that labour mobility increases significantly when a country becomes a member of the EU. It also showed that membership of the euro area is not necessarily associated with a rise in the level of mobility flows. The European Commission (2011) reported that labour mobility in response to macroeconomic shocks has increased significantly in Europe.

The motivation for this study is that although there is a large body of literature on the nature of shocks in Europe, there are no studies that focus on the Visegrad region. For instance, using SVAR, Frenkel and Nickel (2002) studied the relationship between shocks in the euro area and in Central and Eastern European countries (CEECs). Their results showed that there were some differences in the shocks and adjustment processes between the euro area and the CEECs. Fidrmuc and Korhonen (2003) continued the analysis of Bayoumi and Eichengreen (1993) but included CEECs. Their results showed that Hungary and Estonia had the highest share of correlated supply shocks with the euro area. The authors attributed this observation to the impact of foreign direct investment inflow and high trade relations. They also found a low degree of correlation of shocks for other CEECs. Fidrmuc and Korhonen's (2003) study of business cycle correlations between the euro area and the transition countries showed that Poland, Slovenia and Hungary had a very high degree of correlation of shocks with the euro area.

Horvath (2000) analysed the correlation of demand and supply shocks between the Visegrad countries and the Baltic countries. His results showed that Hungary had the highest correlation of supply shocks and the lowest correlation of aggregate demand shocks. Weimann (2002) reported that the Czech Republic, Bulgaria and Hungary had the strongest correlation of demand shocks with the euro area. Given the structural differences in the economies of European countries, Frenkel and Nickel (2002) concluded that there was a significant difference in shocks and the speed of adjustment between CEECs and the euro area.

Arfa (2009) found that several new member countries of the EU had high correlation of demand shocks with the euro area while the observed supply shocks were asymmetric. Socol and Soviani (2010) and Socol and Măntescu (2011) associated weak correlation of demand shocks with differences in national fiscal policies among the countries. According to Janus and Beck (2014), the Visegrad region is characterised by low correlation of shocks or disturbances. In their study, correlation of supply shocks in the Visegrad countries was lower than in any other analysed sample, with Poland and the Czech Republic characterised by high correlation of demand shocks. Their results also showed a sharp increase in the correlation of supply shocks at the start of the global financial crisis.

Baxter and Koutraparitsas (2004) concluded that trade plays an influential role in the synchronisation of shocks. Beck (2014) found that structural similarities and differences in GDP per capita play a significant 
role in the synchronisation of economic shocks. Sachs and Schleer (2013) showed that structural reforms and labour market institutions play a crucial role in the coherence of shocks. Lehwald (2012) concluded that the synchronisation of shocks in the Eurozone is attributed to global factors rather than regional ones. In relation to this, Lee and Azali (2010) found that the main driver of synchronised shocks was international trade. In support of this conclusion, Silvestre et al. (2009) emphasised the role of diminishing trade in the correlation of shocks.

Although many studies explain the nature and synchronisation of shocks, the question of how important labour mobility (migration) is in the process of adjustment of the Visegrad countries to shocks has not been addressed. Since the formation of a monetary union reduces the potential of countries to respond to asymmetric shocks through macroeconomic policy, the role of labour mobility has received significant attention. This study focuses on labour mobility and its ability to act as an adjustment mechanism to counteract asymmetric shocks in the Visegrad countries following the approach of Dao et al. (2014) and Beyer and Smets (2015).

According to Mayda (2006), labour mobility faces some limitations due to negative individual perceptions and attitudes towards migration, thus reducing its influence as a mechanism of adjustment to asymmetric shocks. A study conducted by the Organization for Economic Cooperation and Development (OECD) (2012) concluded that labour mobility across EU member countries was low despite a rise in migration across countries. Similarly, Barslund and Busse (2014) reported that in 2013, only $4 \%$ of working-age EU citizens lived in a different EU country.

Decressin and Fatás (1995) assessed regional labour mobility in the EU, comparing their results to those of the US. Their results show a low response of labour mobility to macroeconomic activity rates in the EU. They concluded that in Europe, it is only after the third year that the influence of labour mobility is observed in response to changes in activity rates. Dao et al. (2014) found that labour mobility has increased in Europe though it is still lower than in the US. Beyer and Smets (2015) investigated labour mobility in the US and Europe and concluded that labour mobility's responsiveness to asymmetric shocks is higher in the US than in Europe. Similarly, L'Angevin (2007) found a low rate of labour mobility in the euro area countries than in the US. He concluded that unemployment takes a longer time to return to an equilibrium after a shock in the euro area. Beyer and Smets (2015) also found that labour mobility in the EU region was low.

\section{Methodology}

This study focuses on two research questions. The first aims to investigate the nature and correlation of demand and supply shocks in the Visegrad countries (the Czech Republic, Hungary, Poland and Slovakia) while the second aims to assess the role of labour mobility in the process of adjustment to asymmetric shocks in the Visegrad region. The first research question is answered using SVAR models following the approach of Blanchard and Quah (1989) and Bayoumi and Eichengreen (1993). This approach focuses on the aggregate demand and aggregate supply (AD - AS) framework of demand and supply shocks. The second question is answered using panel cointegrated ARDL models following the approach of Pesaran et al. (1999). This approach is chosen because of the efficacy of pooled mean group (PMG) models to estimate both short-term and long-term effects of phenomena. It allows for a variation in short-term coefficients according to specific conditions in each country but restricts long-term coefficients to be homogenous across the Visegrad countries.

The main variables for the first research question include the World Uncertainty Index (WUI), real domestic GDP, exchange rate, and price level or inflation. The WUI is used to measure the impact of external supply shocks. The index is the unbalanced GDP weighted average for 142 countries. It takes into consideration all global events that affect economic activities in countries. The use of this variable instead of the conventional global GDP follows the approach of Ahir et al. (2019). Real domestic GDP is used to measure the effect of domestic supply shocks. It is measured in millions of euros. The exchange rate is measured using the real effective exchange rate, and the price level or inflation is measured using the Consumer Price Index (CPI). These variables are chosen following the approach of Blanchard and Quah (1989) and Bayoumi and Eichengreen (1993).

Data for the variables is obtained from Eurostat and the OECD. The WUI and real domestic GDP are transformed into natural logarithmic forms. The inflation rate and the exchange rate are in percentage, and therefore no logarithms are applied. A shock to real domestic GDP is chosen as supply shocks since it has been shown that this is the main driver of output fluctuations in countries (see e.g. Rand and Tarp 2001). Shocks to the real exchange rate are aligned with aggregate demand shocks. Shocks to inflation are restricted to nominal shocks that only have temporary effects due to short-term price stickiness. The paper assumes that in the long term, money is neutral.

The study performs time series verifications, including a stationarity test, lag order selection and a cointegration test. The stationarity test is performed using the Augmented Dickey-Fuller test (Dickey and Fuller 
1979). Lag order selection is performed using Akaike Information Criterion (Akaike 1974), Hannan-Quinn Information Criterion (Hannan-Quinn 1979) and Schwarz Information Criterion (Schwarz 1978). The cointegration test is performed using the Johansen test of cointegration (Johansen 1988). Optimum lags were decided using a lag frequency test. The results of the unit root test show that all the variables are integrated of order one. The cointegration test shows no case of cointegration among the variables. Therefore, the first difference stationary specification for all the SVAR models is chosen, which was also applied by authors such as Bayoumi and Eichengreen (1993) and Campos and Macchiarelli (2016). The VAR model is specified in Eq. (1):

$$
\begin{aligned}
& y_{t}=A_{1} y_{t-1}+\cdots+A_{k} y_{t-k}+e_{t} \\
& E\left(e_{t} e_{t}^{\prime}\right)=\sum
\end{aligned}
$$

where $y_{t}$ is a vector of $\mathrm{n}$ endogenous variables, $y_{t}=\left(\Delta y_{t}^{E X}, \Delta y_{t}, \Delta d_{t}, \Delta m_{t}\right)$

$\Delta y_{t}^{E X}$ represents the first-order difference of the WUI, $\Delta y_{t}$ represents the first-order difference of real domestic GDP, $\Delta d_{t}$ represents the first-order difference of real effective exchange rate, and $\Delta m_{t}$ represents the firstorder difference of CPI inflation. $A_{i}$ are coefficient matrices, $e_{t}$ are error terms, and $\Sigma$ is the covariance matrix of the errors. The modification of VAR to allow for contemporaneous relationships among the model variables gives an SVAR model as expressed in (3).

$$
A y_{t}=C_{1} y_{t-1}+\cdots+C_{k} y_{t-k}+e_{t}
$$

A new notation $\left(C_{i}\right)$ is formulated because when matrix $\mathrm{A}$ is not an identity matrix, the $C_{i}$ will generally differ from the $A_{i}$ in the reduced-form VAR. The A matrix characterises the contemporaneous relationships among the variables in the VAR. Error terms are decomposed into mutually orthogonal shocks. The solution is to write the errors as a linear combination of structural shocks:

$$
e_{t}=B \mu_{t}
$$

where $B$ is a $4 \times 4$ matrix of structural coefficients and is a vector of structural shocks such that.

$\varepsilon=\left(\varepsilon_{t}^{E X}, \varepsilon_{t}^{D S}, \varepsilon_{t}^{D D}, \varepsilon_{t}^{M}\right)^{\prime}$,consisting of external GDP shock $\left(\varepsilon_{t}^{E X}\right)$, domestic supply shock $\left(\varepsilon_{t}^{D S}\right)$, domestic demand shock $\left(\varepsilon_{t}^{D D}\right)$, and monetary shock $\left(\varepsilon_{t}^{M}\right)$ respectively. It is assumed that they are serially uncorrelated and orthonormal, with a variance-covariance matrix normalised to the identity matrix. The condition of $E\left(\mu_{t} \mu_{t}^{\prime}\right)=I$ is imposed. Equations 3 and 4 are combined to obtain the SVAR model:

$$
A y_{t}=C_{1} y_{t-1}+\cdots+C_{k} y_{t-k}+B \mu_{t}
$$

Given that A is invertible, the SVAR is written as

$$
y_{t}=A^{-1} C_{1} y_{t-1}+\cdots+A^{-1} C_{k} y_{t-k}+A^{-1} B \mu_{t}
$$

which implies the following set of relationships:

$$
A^{-1} C_{i}=A_{i}
$$

For $i=1,2,3 \ldots$

$$
A^{-1} B B^{\prime} A^{-1^{\prime}}=\sum
$$

Cholesky identification is used to derive the B matrix, and the study relies on some assumptions based on economic theory. First, external supply is assumed to be strictly exogenous. This is plausible since all the Visegrad economies are relatively small and open economies, making no significant contribution to global output. Second, domestic supply is affected only by shocks to external supply and shocks from itself. Third, the real effective exchange rate is assumed to be affected by shocks to external supply, shocks to domestic supply, and domestic demand shocks. The domestic price level is assumed to be strictly endogenous, implying that prices are affected by shocks to external supply, shocks to domestic supply, demand shocks, and monetary shocks.

The study normalises the variance-covariance matrix of structural shocks to identity following the identification of Blanchard and Quah (1989) and Clarida and Gali (1994), which is the extended form of the former. The method uses a C-Model, as used by Amisano and Giannini (1997). The theoretical foundations are explained using an AS - AD framework. The assumptions behind structural shocks are expressed in Eq. (9):

$$
\left(\begin{array}{c}
\Delta y_{t}^{E X} \\
\Delta y_{t} \\
\Delta \mathrm{d}_{t} \\
\Delta \mathrm{m}_{t}
\end{array}\right)=\sum_{i=0}^{\infty} L^{i}\left(\begin{array}{llll}
a_{11 i} & a_{12 i} & a_{13 i} & a_{14 i} \\
a_{21 i} & a_{22 i} & a_{23 i} & a_{24 i} \\
a_{31 i} & a_{32 i} & a_{33 i} & a_{34 i} \\
a_{41 i} & a_{42 i} & a_{43 i} & a_{44 i}
\end{array}\right)\left(\begin{array}{c}
\varepsilon_{t}^{E X} \\
\varepsilon_{t}^{D S} \\
\varepsilon_{t}^{D D} \\
\varepsilon_{t}^{M}
\end{array}\right)
$$

where $\Delta y_{t}^{E X}, \Delta y_{t}, \Delta \mathrm{d}_{t}$ and $\Delta \mathrm{m}_{t}$ denote the first difference form of WUI, real domestic GDP, the real effective exchange rate, and the price level respectively. $\varepsilon_{t}^{E X}$, $\varepsilon_{t}^{D S}, \varepsilon_{t}^{D D}$ and $\varepsilon_{t}^{M}$ represent external shocks, real domestic supply shocks, domestic demand shocks, and monetary shocks respectively. The matrix of 'a' coefficients is a $4 \times 4$ matrix defining the impulse responses of the variables to structural shocks. Detailed information about the VAR and SVAR models is provided in the work of Amisano and Giannini (1997) and Lütkepohl (2005). Demand shocks and nominal shocks have no effect on output in the long term; thus: 


$$
\sum_{i=0}^{\infty} a_{13 i}=\sum_{i=0}^{\infty} a_{14 i}=0
$$

Furthermore, exchange rate is not affected by nominal shocks in the long term (see Lütkepohl, 2005; Amisano and Giannini, 1997); thus:

$$
\sum_{i=0}^{\infty} a_{34 i}=0
$$

Therefore, the matrix of structural coefficients (see Lütkepohl, 2005; Amisano and Giannini, 1997) is expressed as:

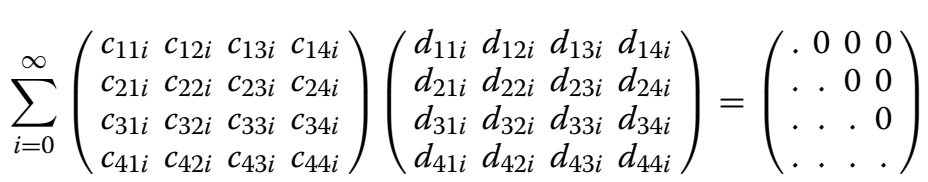

unemployment and economic growth among the Visegrad countries.

The variables for the second research question are employment, migration (labour mobility), technology, and real value added. Employment is measured in percentages and represents the percentage of employment of EU labour except the reporting country. Migration or labour mobility is measured using the net migration value, which is the difference between immigration and emigration. It is in thousands of people. Technology is measured using total factor productivity, as used by Ngai and Pissarides (2007). Real value added is measured in millions of euros and is derived
Pairwise correlations of shocks are examined across the four Visegrad countries. When the correlation coefficients of shocks between two countries are positive and statistically significant, it implies symmetry, whereas negative correlation coefficients or statistically insignificant coefficients indicate asymmetry. Statistical significance in the results is depicted by an asterisk (*). If there is symmetry of shocks between or among countries, it means that the countries require a synchronous policy response to that macroeconomic shock. The test for the statistical significance of the coefficients is carried out using Kendall and Stuart's (1973) correlation statistic at the 5\% level. This statistic is chosen since it offers more power than other parametric tests such as the Pearson productmoment correlation coefficient (Yue et al. 2002).

The second research question is answered using a cointegrated panel ARDL model following the approach of Pesaran et al. (1999). It seeks to assess the effectiveness of labour mobility as an alternative adjustment mechanism to shocks in the Visegrad region. This study uses migration and labour mobility interchangeably, as used in the report of the European Commission (2011). This report highlighted the importance of the movement of workers from one EU country to another as an important adjustment mechanism for the European economies. A study conducted by Arpaia et al. (2016) showed that countries joining the EU increases labour mobility significantly. It also found that membership of the euro area is not associated with a rise in the level of labour mobility. The European Commission (2011) reported that movements in response to shocks have increased significantly in Europe. Since the start of the global financial crisis, attention has turned to labour mobility as a counter measure for the divergence in as the ratio of gross value added to the GDP deflator. The paper acknowledges that there are other determinants of employment, but it seeks to estimate the unique impact of migration and technological progress. The effect of other employment determinants is incorporated into real value added. Data for all the variables is in quarterly frequencies and ranges from 2000q1 to 2020q1 (where q represents quarter). All the variables are transformed into logarithmic forms except employment since it is in percentage.

There has been increased interest in dynamic panel models in recent years due to cross-country analyses. In this regard, the study considers Mean Group (MG) and PMG models. The PMG approach proposed by Pesaran et al. (1999) accounts for panel heterogeneity and endogeneity of variables and allows for estimation with $\mathrm{I}(0)$ and I(1) variables. It estimates both short run and long run coefficients but uniquely restricts short run coefficients to individual countries and imposes common long run coefficients on all countries. The choice of the MG model and PMG model is based on the Hausman test (Hausman 1978). The null hypothesis of this test is long run slope homogeneity (PMG). Failure to reject the null hypothesis indicates that PMG is more appropriate. The Hausman test results for this paper show that PMG is more appropriate, and therefore the study estimates both the long run and short run coefficients for technological progress, migration (labour mobility) and real value added. With PMG models, the focus is on the long run coefficients and the speed of adjustment parameters.

The study performs a unit root test (Levin and Lin 1992) to check for the stationary properties of the data and a test of panel cointegration using the Kao test (Kao 
1999). The lags for the variables are determined using the Akaike Information Criterion (AIC) (Akaike 1974). Structural breaks are taken into consideration, as the period covered by the study includes major events such as the global financial crisis. Ignoring structural breaks can lead to inaccurate inferences. In this regard, the paper divides the dataset into two samples: 2000-2007 and 2008-2019. The first period is the period before the crisis and the second is the period after the crisis. The Chow test (Chow 1960) is used to determine the significance of breaks. The null hypothesis of this test is no structural break against the alternative that there is a known structural break in 2008. With this test, the coefficients of the two periods are estimated. The F test is then computed using out-ofsample forecast errors. The stability of the coefficients for the periods is assured if the null hypothesis of no structural breaks is not rejected. The data is pooled for the whole period (2000-2019) if the test fails to reject the null hypothesis of no structural break. If the null hypothesis is rejected, ARDL models will be constructed differently for the periods before the global financial crisis and after the crisis.

The results of the Chow test show that the null hypothesis is rejected, implying that the intercepts and slopes changed over the two periods. PMG models are therefore run for the period before the crisis and after the crisis. As mentioned earlier, the PMG model constrains the long run coefficients to be identical but allows the intercept, short run coefficients and error variances to differ across groups (Baltagi and Griffin 1997). This allows for variation in the impact of the drivers of employment in the short run while imposing an identical or similar impact from all drivers in the long run across the four Visegrad countries. The economic justification of the PMG model is the fact that the four countries are in the same regional economic bloc and share common policies since they are also all members of the EU. The basic form of the ARDL model according to Pesaran et al. (1999) is specified in Eq. (13):

$$
\begin{aligned}
\Delta \ln M_{i t}= & \alpha_{i}+\sum_{j=1}^{p} \theta_{j} \Delta \ln M_{i t-j} \\
& +\sum_{j=0}^{q}\left[\delta_{j} \Delta \ln V_{i t-j}+\sigma_{j} \Delta \ln F_{i t-j}+\beta_{j} \Delta \ln G_{i t-j}\right] \\
& +\pi_{1} \ln M_{i t-1}+\pi_{2} \ln V_{i t}+\pi_{3} \ln F_{i t}+\pi_{4} \ln G_{i t}+\mu_{i t}
\end{aligned}
$$

The paper denotes specific country fixed effects as $\alpha_{i}$. $M_{i t}$ represents employment of EU labour measured in percentage, $V_{i t}$ represents technological innovation, $F_{i t}$ represents migration or labour mobility, and $G_{i t}$ represents real value added. $\mu_{i t}$ is the error term. $\Delta$ denotes the first-order differencing. The study considers employment and migration (labour mobility) because of the response of labour markets to asymmetric shocks. The more efficient the response is, the better the response of countries to asymmetric shocks (see Dao et al. 2014; Beyer and Smets 2015). Technology is also considered as one of the variables because of the recent wave of technological evolution in workplaces, where there is growing automation of production processes. It thus serves as a shock and therefore plays a crucial role in the dynamics of the labour markets of the four Visegrad countries (see Goos et al. 2014; Bernardi and Garrido 2008; Oesch and Rodriquez-Menes 2011). Furthermore, technology is considered as a variable in labour mobility since with a regional shock to total factor productivity, labour mobility acts to reduce macroeconomic disturbances, thus helping in labour market adjustment given a technological change. Labour mobility also raises the level of volatility in the rest of the region to some degree by exporting unemployment associated with technological change to other areas, where it is absorbed (see Mundell 1961; Hauser 2014; Saks and Wozniak 2011). The magnitude and signs of coefficients are important as they indicate the size and direction of the impact. The speed of adjustment parameters and their signs and significance are also important. A significance level of $0.05(5 \%)$ is used.

In Eq. (13), the short run relationships are explained by the terms with the summation signs. Long run coefficients are interpreted as elasticities and they are the coefficients of the lagged independent variables $\left(\pi_{2}, \pi_{3}\right.$, $\left.\pi_{4}\right)$. These long run coefficients are multiplied by negative one and then divided by $\left(\pi_{1}\right)$. The study chooses the ARDL model by first using the optimal lag structure for each country, which is decided with the help of the AIC and the Bayesian Information Criterion. Next, the study decides on the maximum number of lags for each variable in the ARDL using the lag frequencies. The preferred specification for the two ARDL models is $\operatorname{ARDL}(1,1,1$, 1 ) for the model before the crisis and $\operatorname{ARDL}(1,3,1,1)$ for the model after the crisis. With the data being cointegrated, the error-correction model is an alternative with a general form equivalent to the ARDL model. The presentation of the error correction version of the ARDL model with all the variables in equation one is specified as follows:

$$
\begin{aligned}
\Delta \ln M_{i t}= & \alpha_{i}+\sum_{j=1}^{p-1} \theta_{j} \Delta \ln M_{i t-j} \\
& +\sum_{j=0}^{q-1}\left[\delta_{j} \Delta \ln V_{i t-j}+\sigma_{j} \Delta \ln F_{i t-j}+\beta_{j} \Delta \ln G_{i t-j}\right] \\
& +\gamma_{1} \ln M_{i t-1}+\gamma_{2} \ln V_{i t}+\gamma_{3} \ln F_{i t}+\gamma_{4} \ln G_{i t}+\mu_{i t}
\end{aligned}
$$


$i=1,2,3 \ldots \mathrm{n}$ and the subscript $\mathrm{t}$ is given by $t=1,2,3 \ldots \mathrm{T}$. The number of countries is represented by $n$. Time is represented by $t$. The number of lags is represented by $j$. The speed of adjustment parameter which is also called the error correction term (ECT) is represented by $\gamma_{1}$, as in Eq. (14). The signs of its coefficient are important in the interpretation of convergence and divergence from the equilibrium. A positive $\gamma_{1}$ indicates a divergence and a negative $\gamma_{1}$ indicates convergence towards the equilibrium. In the error correction version of the ARDL model, short run coefficients $\left(\theta_{j}, \delta_{j}, \sigma_{j}\right.$ and $\beta_{j}$ ) are directly estimated. They can differ across countries. The long run coefficients are constrained for the group of Visegrad countries. The long run coefficients are $\gamma_{1}, \gamma_{2}, \gamma_{3}, \gamma_{3}$ and $\gamma_{4}$. Chapter four presents, interprets and discusses the results of the study. The results are generated in STATA version 15.

\section{Results}

This section provides economic interpretations of the results obtained in the SVAR models and the cointegrated panel ARDL models. The first section describes the nature of shocks in the Visegrad countries. The second section explains the impact of labour mobility in the process of adjustment to asymmetric shocks in the Visegrad countries.

\subsection{Similarities and differences in economic structures of Visegrad countries}

This section briefly discusses the economic structures of the four countries with an emphasis on similarities and differences. This helps to understand the dynamics of responses to shocks across the region. Figure 1 shows the export dependence of the four Visegrad countries and the trajectory of GDP growth. It is observed that all four countries have experienced an increased contribution of exports to GDP. The highest share of exports in GDP is in Slovakia with a value above $90 \%$. Hungary has the next highest share of about $80 \%$, the Czech Republic has a share of about $75 \%$, and Poland has the lowest share of about $50 \%$. The share of exports in GDP partly explains the vulnerability of a country to external demand shocks. High export dependence means a high impact of external shocks.

Figure 2 shows the level of real GDP per capita, inflation and unemployment in the four countries. Real GDP per capita is rising in all the countries, with the highest rise occurring in the Czech Republic, followed by Slovakia. Hungary and Poland have a very similar level of real GDP per capita. It is also observed that the level
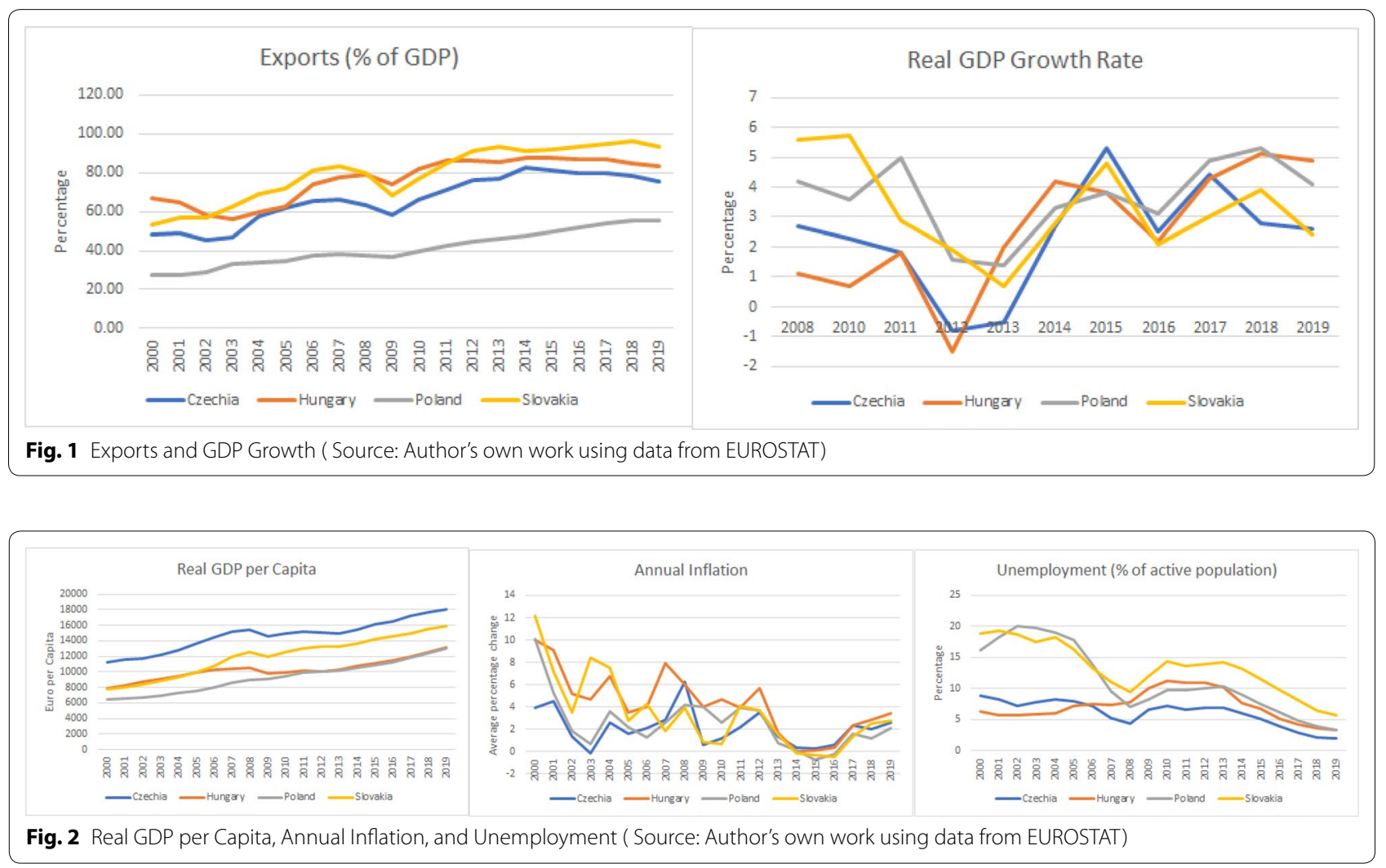
of inflation has declined across all the countries even though it shows more volatility in its movement. There is some degree of convergence as all the countries move towards the same level. The lowest inflation rate is in Poland and the highest is in Hungary. There is a similar result for the level of unemployment, which has declined over the years. It shows some level of convergence across the countries. The lowest unemployment rate is in the Czech Republic and the highest is in Slovakia.

Figure 3 shows the trade concentration and trade diversification indices for the four countries. The trade concentration index measures how reliant a country is on a limited group of commodities as its main foreign exchange source. It ranges between 0 and 1 . Zero implies perfect diversification and 1 indicates concentration on a single product. The trade concentration index also tells us whether the observed large share of exports comes from a small number of products or exports are distributed widely among many products. This index is important since it signals how vulnerable a country is to external shocks. How it evolves over time provides vital information about the changing productive structure of a country. The trade concentration values observed are closer to zero than 1 , indicating low trade concentration. According to the United Nations Conference on Trade and Development (UNCTAD 2020), the trade diversification index shows the difference between the trade structure of a country or country group and the world average. It ranges between 0 and 1 . A value closer to 1 indicates a bigger difference from the world average.

\subsection{The nature and correlation of shocks before and after the financial crisis}

Table 1 shows the SVAR results of the Czech Republic. Positive coefficients indicate a positive response to shocks and negative coefficients imply a negative response to shocks. Before the global financial crisis, a shock to the WUI had a negative impact on real domestic GDP in the Czech Republic. Furthermore, it had a positive impact on the exchange rate and a negative impact on the price level. The impact of real domestic supply shocks on the exchange rate and the price level was positive. The impact of demand shocks on the price level was positive. After the crisis, a positive shock to the WUI had a positive impact on real domestic GDP. The impact on the exchange rate and the price level remained the same as before the crisis. A positive shock to real domestic supply impacted negatively on the exchange rate and the price level. The impact of demand shocks on the price level changed to negative.

Table 2 shows the SVAR results of Hungary. All the unrestricted entries are statistically significant. The signs of the coefficients show the nature of response to shocks. Positive coefficients show a positive response, and vice versa. Before the crisis, shock to the WUI had a negative impact on real domestic GDP, the exchange rate and the price level. The impact of real domestic supply shocks on the exchange rate and the price level was negative. The impact of demand shocks on the price level was positive. After the crisis, a shock to the WUI impacted positively on real domestic GDP and the exchange rate but negatively on the price level. The impact of real domestic supply shocks on the exchange rate and the price level remained the same (negative). The impact of demand shocks on the price level changed to negative.

Table 3 shows the SVAR results of Poland. It shows that before the global financial crisis, the impact of a shock to the WUI was negative on domestic GDP and the exchange rate in Poland. The impact on the price level was positive, however. Real domestic supply shocks had negative impact on the exchange rate and positive impact on the price level. The impact of demand shocks on the price level was negative. After the crisis, the impact of a shock to the WUI remained negative on domestic GDP but positive on the exchange rate and negative on the price level. A shock to real domestic supply impacted negatively on the exchange rate and the price level. The

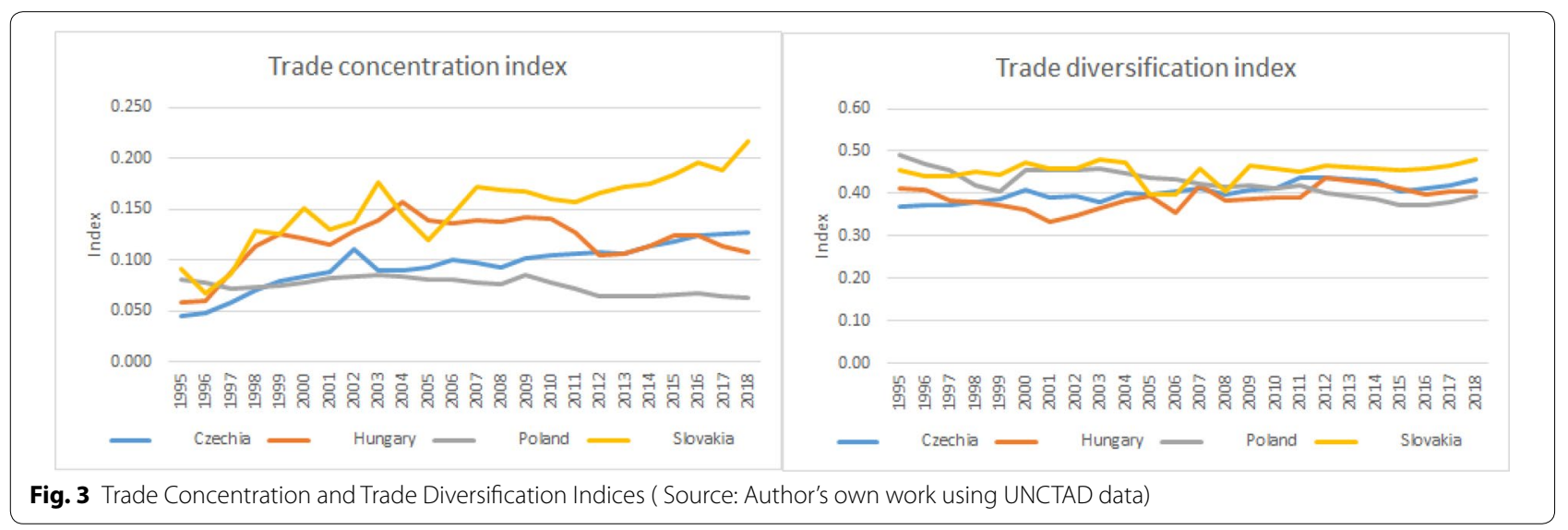


Table 1 SVAR results of Czech Republic before and after crisis

\begin{tabular}{|c|c|c|c|c|}
\hline & \multicolumn{2}{|l|}{ Before crisis } & \multicolumn{2}{|l|}{ After crisis } \\
\hline & Coefficient & Std. error & Coefficient & Std. error \\
\hline /a_1_1 & 1 & (Constrained) & 1 & (Constrained) \\
\hline /a_2_1 & $-0.36^{* * *}$ & 0.023 & $0.1 * * *$ & 0.025 \\
\hline /a_3_1 & $0.12^{* * *}$ & 0.011 & $0.18^{* * *}$ & 0.008 \\
\hline /a_4_1 & $-0.423^{* * *}$ & 0.106 & $-0.42^{* * *}$ & 0.0518 \\
\hline /a_1_2 & 0 & (Constrained) & 0 & (Constrained) \\
\hline /a_2_2 & 1 & (Constrained) & 1 & (Constrained) \\
\hline /a_3_2 & $0.62^{* * *}$ & 0.1 & $-0.118^{* *}$ & 0.049 \\
\hline /a_4_2 & $1.122^{* * *}$ & 0.095 & $-4.578^{* * *}$ & 0.329 \\
\hline /a_1_3 & 0 & (Constrained) & 0 & (Constrained) \\
\hline /a_2_3 & 0 & (Constrained) & 0 & (Constrained) \\
\hline /a_3_3 & 1 & (Constrained) & 1 & (Constrained) \\
\hline /a_4_3 & $4.018^{* * *}$ & 0.211 & $-5.515^{* * *}$ & 0.946 \\
\hline /a_1_4 & 0 & (Constrained) & 0 & (Const \\
\hline /a_2_4 & 0 & (Constrained) & 0 & (Constrained) \\
\hline /a_3_4 & 0 & (Constrained) & 0 & (Constrained) \\
\hline /a_4_4 & 1 & (Constrained) & 1 & (Constrained) \\
\hline /b_1_1 & $0.231^{* * *}$ & 0.037 & $0.29 * * *$ & 0.031 \\
\hline /b_2_1 & 0 & (Constrained) & 0 & (Constrained) \\
\hline /b_3_1 & 0 & (Constrained) & 0 & (Constrained) \\
\hline /b_4_1 & 0 & (Constrained) & 0 & (Con \\
\hline /b_1_2 & 0 & (Constrained) & 0 & (Constrained) \\
\hline /b_2_2 & $0.024^{* * *}$ & 0.004 & $0.048^{* * *}$ & 0.005 \\
\hline /b_3_2 & 0 & (Constrained) & 0 & (Constrained) \\
\hline /b_4_2 & 0 & (Constrained) & 0 & (Constrained) \\
\hline /b_1_3 & 0 & (Constrained) & 0 & (Constrained) \\
\hline /b_2_3 & 0 & (Constrained) & 0 & (Constrained) \\
\hline /b_3_3 & $0.011^{* * *}$ & 0.002 & $0.016^{* * *}$ & 0.002 \\
\hline /b_4_3 & 0 & (Constrained) & 0 & (Constrained) \\
\hline /b_1_4 & 0 & (Constrained) & 0 & (Constrained) \\
\hline /b_2_4 & 0 & (Constrained) & 0 & (Constrained) \\
\hline /b_3_4 & 0 & (Constrained) & 0 & (Constrained) \\
\hline /b_4_4 & 1 & (Constrained) & 1 & (Constrained) \\
\hline \multicolumn{5}{|c|}{$\begin{array}{l}\text { LR test of identifying restrictions: } \operatorname{chi} 2(1)=43.18, \text { Prob }>\text { chi } 2=0.000, \\
\text { Number of obs. }=20, \text { Log likelihood }=91.10228 . \text { LR test of identifying } \\
\text { restrictions: } \operatorname{chi} 2(1)=14.16, \text { Prob }>\text { chi } 2=0.000, \text { Number of obs. }=45, \text { Log } \\
\text { likelihood }=136.9166\end{array}$} \\
\hline \multicolumn{5}{|c|}{$\begin{array}{l}\text { /a_1_1 represents own shock for global GDP, /a_2_1 represents a shock from } \\
\text { global GDP to domestic supply, /a_3_1 represents a shock from global GDP to } \\
\text { the exchange rate, /a_4_1 represents a shock from global GDP to price level. } \\
\text { /a_1_2 represents a domestic supply shock to global GDP, /a_2_2 represents } \\
\text { own domestic supply shock, /a_3_2 represents domestic supply shock to } \\
\text { exchange rate, /a_4_2 represents domestic supply shock to price level. /a_1_3 } \\
\text { represents demand shock to global GDP, /a_2_3 represents demand shock to } \\
\text { domestic supply, /a_3_3 represents own demand shock, /a_4_3 represents } \\
\text { demand shock to price level, /a_1_4 represents monetary shock to global } \\
\text { GDP, /a_2_4 represents monetary shock to domestic supply, /a_3_4 represents } \\
\text { monetary shock to exchange rate, /a_4_4 represents monetary shock to } \\
\text { price level. /b_1_1, /b_2_2 and /b_3_3 are own shocks. ** denotes statistical } \\
\text { significance of coefficients at 5\% level, and *** denotes statistical significance of } \\
\text { coefficients at } 1 \% \text { level }\end{array}$} \\
\hline
\end{tabular}

Table 2 SVAR results of Hungary before and after crisis

\begin{tabular}{|c|c|c|c|c|}
\hline & Before crisis & & After crisis & \\
\hline & Coefficient & Std. error & Coefficient & Std. error \\
\hline /a_1_1 & 1 & (Constrained) & 1 & (Constrained) \\
\hline /a_2_1 & $-0.612^{* * *}$ & 0.045 & $0.1^{* *}$ & 0.041 \\
\hline /a_3_1 & $-0.528^{* * *}$ & 0.011 & $0.041^{* *}$ & 0.016 \\
\hline /a_4_1 & $-0.147^{* *}$ & 0.0662 & -0.309 & 0.621 \\
\hline /a_1_2 & 0 & (Constrained) & 0 & (Constrained) \\
\hline /a_2_2 & 1 & (Constrained) & 1 & (Constrained) \\
\hline /a_3_2 & $-0.111^{* *}$ & 0.05 & $-0.083^{* *}$ & 0.041 \\
\hline /a_4_2 & $-0.396^{* * *}$ & 0.115 & $-2.276^{* * *}$ & 0.238 \\
\hline /a_1_3 & 0 & (Constrained) & 0 & (Constrained) \\
\hline /a_2_3 & 0 & (Constrained) & 0 & (Constrained) \\
\hline /a_3_3 & 1 & (Constrained) & 1 & (Constrained) \\
\hline /a_4_3 & $0.39 * * *$ & 0.113 & $-3.248^{* * *}$ & 0.6464 \\
\hline /a_1_4 & 0 & (Constrained) & 0 & (Constrained) \\
\hline /a_2_4 & 0 & (Constrained) & 0 & (Constrained) \\
\hline /a_3_4 & 0 & (Constrained) & 0 & (Constrained) \\
\hline /a_4_4 & 1 & (Constrained) & 1 & (Constrained) \\
\hline /b_1_1 & $0.298^{* * *}$ & 0.041 & $0.292^{* * *}$ & 0.035 \\
\hline /b_2_1 & 0 & (Constrained) & 0 & (Constrained) \\
\hline /b_3_1 & 0 & (Constrained) & 0 & (Constrained) \\
\hline /b_4_1 & 0 & (Constrained) & 0 & (Constrained) \\
\hline /b_1_2 & 0 & (Constrained) & 0 & (Constrained) \\
\hline /b_2_2 & $0.068^{* * *}$ & 0.009 & $0.087^{* * *}$ & 0.011 \\
\hline /b_3_2 & 0 & (Constrained) & 0 & (Constrained) \\
\hline /b_4_2 & 0 & (Constrained) & 0 & (Constrained) \\
\hline /b_1_3 & 0 & (Constrained) & 0 & (Constrained) \\
\hline /b_2_3 & 0 & (Constrained) & 0 & (Constrained) \\
\hline /b_3_3 & $0.017^{* * *}$ & 0.002 & $0.027^{* * *}$ & 0.003 \\
\hline /b_4_3 & 0 & (Constrained) & 0 & (Constrained) \\
\hline /b_1_4 & 0 & (Constrained) & 0 & (Constrained) \\
\hline /b_2_4 & 0 & (Constrained) & 0 & (Constrained) \\
\hline /b_3_4 & 0 & (Constrained) & 0 & (Constrained) \\
\hline /b_4_4 & 1 & (Constrained) & 1 & (Constrained) \\
\hline
\end{tabular}

LR test of identifying restrictions: $\operatorname{chi} 2(1)=93.66$, Prob $>$ chi2 $=0.000$,

Number of obs. $=26$, Log likelihood $=72.19042$. LR test of identifying restrictions: $\operatorname{chi} 2(1)=18.48$, Prob $>$ chi2 $=0.000$, Number of obs. $=34$, Log likelihood $=67.38943$

** denotes statistical significance of coefficients at $5 \%$ level, and ${ }^{* * *}$ denotes statistical significance of coefficients at $1 \%$ level

impact of demand shocks on the price level remained negative.

Table 4 shows the SVAR results of Slovakia. All the entries are statistically significant. Before the financial crisis, the impact of a shock to the WUI was positive on real domestic GDP and the price level but negative on the 
Table 3 SVAR results of Poland before and after crisis

\begin{tabular}{|c|c|c|c|c|}
\hline & Before crisis & & After crisis & \\
\hline & Coefficient & Std. error & Coefficient & Std. error \\
\hline /a_1_1 & 1 & (Constrained) & 1 & (Constrained) \\
\hline /a_2_1 & $-0.14^{* * *}$ & 0.044 & $-0.09^{* *}$ & 0.045 \\
\hline /a_3_1 & $-0.071^{* * *}$ & 0.021 & $0.24^{* * *}$ & 0.02 \\
\hline /a_4_1 & $0.233^{* * *}$ & 0.068 & $-0.31^{* * *}$ & 0.063 \\
\hline /a_1_2 & 0 & (Constrained) & 0 & (Constrained) \\
\hline /a_2_2 & 1 & (Constrained) & 1 & (Constrained) \\
\hline /a_3_2 & $-0.238^{* *}$ & 0.091 & $-0.163^{* *}$ & 0.076 \\
\hline /a_4_2 & $0.124^{* * *}$ & 0.0338 & $-0.450^{* *}$ & 0.221 \\
\hline /a_1_3 & 0 & (Constrained) & 0 & (Constrained) \\
\hline /a_2_3 & 0 & (Constrained) & 0 & (Constrained) \\
\hline /a_3_3 & 1 & (Constrained) & 1 & (Constrained) \\
\hline /a_4_3 & $-1.444^{* *}$ & 0.648 & $-0.891^{* *}$ & 0.337 \\
\hline /a_1_4 & 0 & (Constrained) & 0 & (Constrained) \\
\hline /a_2_4 & 0 & (Constrained) & 0 & (Constrained) \\
\hline /a_3_4 & 0 & (Constrained) & 0 & (Constrained) \\
\hline /a_4_4 & 1 & (Constrained) & 1 & (Constrained) \\
\hline /b_1_1 & $0.289 * * *$ & 0.04 & $0.283^{* * *}$ & 0.034809 \\
\hline /b_2_1 & 0 & (Constrained) & 0 & (Constrained) \\
\hline /b_3_1 & 0 & (Constrained) & 0 & (Constrained) \\
\hline /b_4_1 & 0 & (Constrained) & 0 & (Constrained) \\
\hline /b_1_2 & 0 & (Constrained) & 0 & (Constrained) \\
\hline /b_2_2 & $0.065^{* * *}$ & 0.009 & $0.074^{* * *}$ & 0.009097 \\
\hline /b_3_2 & 0 & (Constrained) & 0 & (Constrained) \\
\hline /b_4_2 & 0 & (Constrained) & 0 & (Constrained) \\
\hline /b_1_3 & 0 & (Constrained) & 0 & (Constrained) \\
\hline /b_2_3 & 0 & (Constrained) & 0 & (Constrained) \\
\hline /b_3_3 & $0.03^{* * *}$ & 0.004 & $0.032^{* * *}$ & 0.003988 \\
\hline /b_4_3 & 0 & (Constrained) & 0 & (Constrained) \\
\hline /b_1_4 & 0 & (Constrained) & 0 & (Constrained) \\
\hline /b_2_4 & 0 & (Constrained) & 0 & (Constrained) \\
\hline /b_3_4 & 0 & (Constrained) & 0 & (Constrained) \\
\hline /b_4_4 & 1 & (Constrained) & 1 & (Constrained) \\
\hline
\end{tabular}

exchange rate. The impact of real domestic supply shocks on the exchange rate and the price level was negative. The impact of demand shocks on the price level was positive. After the financial crisis, a shock to the WUI impacted negatively on domestic GDP, the exchange rate and the price level. A shock to real domestic supply impacted negatively on the exchange rate and positively on the price level. The impact of domestic demand shocks on the price level remained positive.
Table 4 SVAR results of Slovakia before and after crisis

\begin{tabular}{|c|c|c|c|c|}
\hline & \multicolumn{2}{|l|}{ Before crisis } & \multicolumn{2}{|l|}{ After crisis } \\
\hline & Coefficient & Std. error & Coefficient & Std. error \\
\hline /a_1_1 & 1 & (Constrained) & 1 & (Constrained) \\
\hline /a_2_1 & $0.458^{* * *}$ & 0.027 & $-0.035^{* *}$ & 0.015 \\
\hline /a_3_1 & $-0.36^{* * *}$ & 0.095 & $-0.021^{* * *}$ & 0.0002 \\
\hline /a_4_1 & $0.110^{* *}$ & 0.0401 & $-0.23^{* * *}$ & 0.066 \\
\hline /a_1_2 & 0 & (Constrained) & 0 & (Constrained) \\
\hline /a_2_2 & 1 & (Constrained) & 1 & (Constrained) \\
\hline /a_3_2 & $-0.329^{* * *}$ & 0.068 & $-0.08^{* * *}$ & 0.002 \\
\hline /a_4_2 & $-1.663^{* * *}$ & 0.535 & $0.785^{* * *}$ & 0.0535 \\
\hline /a_1_3 & 0 & (Constrained) & 0 & (Constrained) \\
\hline /a_2_3 & 0 & (Constrained) & 0 & (Constrained) \\
\hline /a_3_3 & 1 & (Constrained) & 1 & (Constrained) \\
\hline /a_4_3 & $8.976^{* * *}$ & 0.144 & $1.350^{* * *}$ & 0.452 \\
\hline /a_1_4 & 0 & (Constrained) & 0 & (Constrained) \\
\hline /a_2_4 & 0 & (Constrained) & 0 & (Constrained) \\
\hline /a_3_4 & 0 & (Constrained) & 0 & (Constrained) \\
\hline /a_4_4 & 1 & (Constrained) & 1 & (Constrained) \\
\hline /b_1_1 & $0.281^{* * *}$ & 0.038 & $0.286^{* * *}$ & 0.036 \\
\hline /b_2_1 & 0 & (Constrained) & 0 & (Constrained) \\
\hline /b_3_1 & 0 & (Constrained) & 0 & (Constrained) \\
\hline /b_4_1 & 0 & (Constrained) & 0 & (Constrained) \\
\hline /b_1_2 & 0 & (Constrained) & 0 & (Constrained) \\
\hline /b_2_2 & $0.039 * * *$ & 0.005 & $0.033^{* * *}$ & 0.004269 \\
\hline /b_3_2 & 0 & (Constrained) & 0 & (Constrained) \\
\hline /b_4_2 & 0 & (Constrained) & 0 & (Constrained) \\
\hline /b_1_3 & 0 & (Constrained) & 0 & (Constrained) \\
\hline /b_2_3 & 0 & (Constrained) & 0 & (Constrained) \\
\hline /b_3_3 & $0.013^{* * *}$ & 0.001893 & $0.0003^{* * *}$ & $5.04 \mathrm{e}-05$ \\
\hline /b_4_3 & 0 & (Constrained) & 0 & (Constrained) \\
\hline /b_1_4 & 0 & (Constrained) & 0 & (Constrained) \\
\hline /b_2_4 & 0 & (Constrained) & 0 & (Constrained) \\
\hline /b_3_4 & 0 & (Constrained) & 0 & (Constrained) \\
\hline /b_4_4 & 1 & (Constrained) & 1 & (Constrained) \\
\hline
\end{tabular}

LR test of identifying restrictions: $\mathrm{chi} 2(1)=20.74$, Prob $>\mathrm{chi} 2=0.000$,

Number of obs. $=21$, Log likelihood $=154.1757$. LR test of identifying

restrictions: $\operatorname{chi} 2(1)=38.88$, Prob $>$ chi2 $=0.000$, Number of obs. $=31$, Log likelihood $=224.4755$

** denotes statistical significance of coefficients at $5 \%$ level, and ${ }^{* * *}$ denotes statistical significance of coefficients at $1 \%$ level

\subsection{Correlation of shocks before and after the global financial crisis}

Table 5 shows the correlation of shocks in the Visegrad countries before the global financial crisis. This section is relevant as it shows whether the Visegrad countries will have similar responses to macroeconomic shocks or vice versa. Shocks are correlated if they have the same effect on macroeconomic aggregates in different countries. For example, if external supply shocks affect real domestic 
Table 5 Correlation of shocks before the global financial crisis

\begin{tabular}{|c|c|c|c|c|}
\hline & Czechia & Hungary & Poland & Slovakia \\
\hline \multicolumn{5}{|c|}{ External supply shocks } \\
\hline Czechia & 1 & & & \\
\hline Hungary & 0.0768 & 1 & & \\
\hline Poland & 0.2766 & $0.7911^{\mathrm{a}}$ & 1 & \\
\hline Slovakia & -0.1114 & $0.6636^{\mathrm{a}}$ & 0.3646 & 1 \\
\hline \multicolumn{5}{|c|}{ Domestic supply shocks } \\
\hline Czechia & 1 & & & \\
\hline Hungary & -0.3121 & 1 & & \\
\hline Poland & -0.1541 & 0.1726 & 1 & \\
\hline Slovakia & -0.1089 & 0.1294 & 0.2242 & 1 \\
\hline \multicolumn{5}{|c|}{ Demand shocks } \\
\hline Czechia & 1 & & & \\
\hline Hungary & -0.398 & 1 & & \\
\hline Poland & -0.1627 & 0.0664 & 1 & \\
\hline Slovakia & -0.3088 & 0.1454 & 0.239 & 1 \\
\hline \multicolumn{5}{|c|}{ Monetary shocks } \\
\hline Czechia & 1 & & & \\
\hline Hungary & -0.262 & 1 & & \\
\hline Poland & 0.2782 & 0.1452 & 1 & \\
\hline Slovakia & -0.116 & $0.4812^{\mathrm{a}}$ & -0.0394 & 1 \\
\hline
\end{tabular}

${ }^{a}$ Denotes symmetric shocks at the $5 \%$ level

GDP in the same direction in two different countries, there is a correlation of external supply shocks between the two countries and the policy response can be synchronised. Positive and statistically significant correlation coefficients indicate symmetry while negative correlation coefficients indicate asymmetry. Statistical significance in the results is depicted by an asterisk (*). Positive and significant correlation coefficients imply that countries require a synchronous policy response to counteract similar macroeconomic shocks, and vice versa. The only significant correlation before the crisis relates to external supply shocks and monetary shocks. Hungary correlates with Poland and Slovakia with regard to external supply shocks and with Slovakia only with regard to monetary shocks, making Hungary the country with highest correlation of shocks before the crisis. These correlations of shocks among the countries are referred to as symmetric shocks. In such cases, the countries involved require a similar or synchronous policy to counteract the effects of the shocks. Other correlation coefficients are either negative or not statistically significant, and those indicate asymmetry. Therefore, the countries require different policy responses to mitigate the effects of the shocks. All four countries joined the EU in 2004, which is the middle
Table 6 Correlation of shocks after the global financial crisis

\begin{tabular}{|c|c|c|c|c|}
\hline & Czech & Hungary & Poland & Slovakia \\
\hline \multicolumn{5}{|c|}{ External supply shocks } \\
\hline Czech & 1 & & & \\
\hline Hungary & 0.2591 & 1 & & \\
\hline Poland & $0.6949^{a}$ & 0.3326 & 1 & \\
\hline Slovakia & $0.5624^{\mathrm{a}}$ & $0.3766^{\mathrm{a}}$ & $0.5209^{\mathrm{a}}$ & 1 \\
\hline \multicolumn{5}{|c|}{ Domestic supply shocks } \\
\hline Czech & 1 & & & \\
\hline Hungary & $0.3730^{\mathrm{a}}$ & 1 & & \\
\hline Poland & $0.4580^{\mathrm{a}}$ & $0.5061^{\mathrm{a}}$ & 1 & \\
\hline Slovakia & 0.3333 & $0.3918^{\mathrm{a}}$ & $0.4158^{\mathrm{a}}$ & 1 \\
\hline \multicolumn{5}{|c|}{ Demand shocks } \\
\hline Czech & 1 & & & \\
\hline Hungary & 0.2349 & 1 & & \\
\hline Poland & $0.4972^{\mathrm{a}}$ & $0.4514^{\mathrm{a}}$ & 1 & \\
\hline Slovakia & -0.1362 & 0.0324 & -0.3521 & 1 \\
\hline \multicolumn{5}{|c|}{ Monetary shocks } \\
\hline Czech & 1 & & & \\
\hline Hungary & -0.0622 & 1 & & \\
\hline Poland & 0.1071 & 0.1884 & 1 & \\
\hline Slovakia & 0.0742 & -0.0374 & -0.0191 & 1 \\
\hline
\end{tabular}

${ }^{a}$ Denotes symmetric shocks at the $5 \%$ level

of the data coverage (2000-2007) and before the crisis. It is therefore understandable that there was less coordination of policies, resulting in the high proportion of asymmetric shocks in the region.

Table 6 shows the correlation of shocks after the global financial crisis. It is observed that more symmetries occurred with regard to external supply shocks and domestic supply shocks. There were more asymmetric shocks with respect to demand shocks and monetary shocks. Slovakia had the highest correlation of external supply shocks, followed by the Czech Republic and Poland. Hungary had the highest correlation of domestic supply shocks and Poland had the highest correlation of demand shocks. A variety of structural differences account for these asymmetric demand and monetary shocks, including the influence of the political systems, fiscal policies, differences in legal systems, public purchasing, and the political cycle. Monetary policy had asymmetric shocks largely because of the differences in financial structure among the Visegrad countries. These differences include the influence of banks, levels of consumer debts, and the nature of borrowing (whether at fixed or variable interest rates). The asymmetry in demand and monetary shocks had persisted for some time even before the financial crisis. 


\subsection{The role of labour mobility as an adjustment mechanism to asymmetric shocks}

Figure 4 shows the case of net migration in the four countries. It also shows the total employment of EU workers and non-EU workers. The significance of this figure is the connection it has with labour mobility. The figure shows that the Czech Republic, Hungary and Slovakia had positive net migration while Poland had negative net migration. In the case of the Czech Republic, Hungary and Slovakia, there were more immigrants than emigrants. The opposite occurred in Poland. The Czech Republic had the highest rate of employment of foreign workers but all four countries had a high employment rate of both EU and non-EU nationals.

Figure 5 shows the case of employment of foreign EU workers by gender. The essence of this chart is to show that there is less discrimination in the labour market with regard to employment. The rate of employment is high in all the countries for both men and women. This is therefore an encouragement for workers who intend to seek jobs in other countries in the event of any negative demand and supply shocks.

Figure 6 presents information about the total number of immigrants, emigrants, and net migration as a

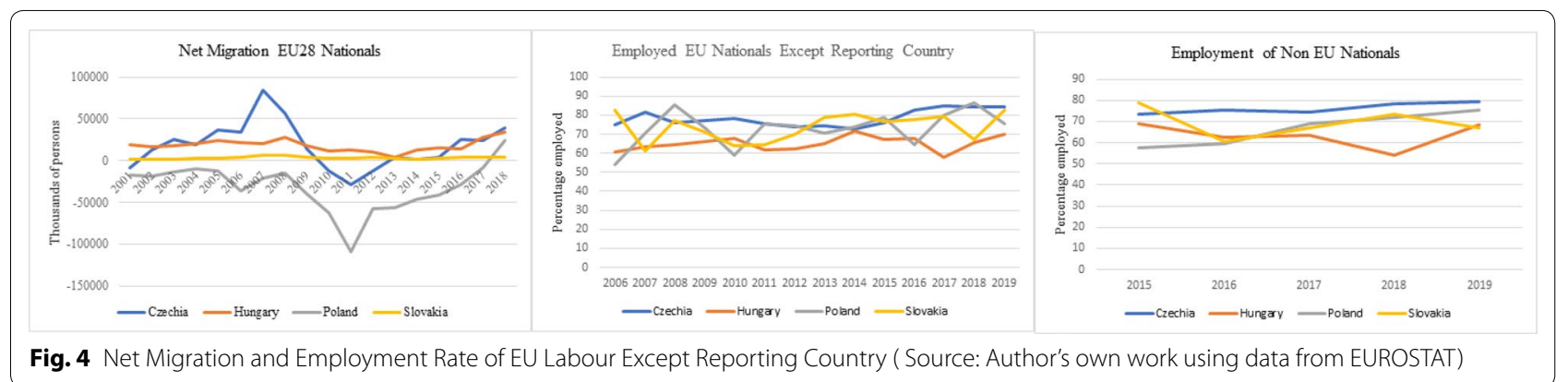

Fig. 4 Net Migration and Employment Rate of EU Labour Except Reporting Country ( Source: Author's own work using data from EUROSTAT)
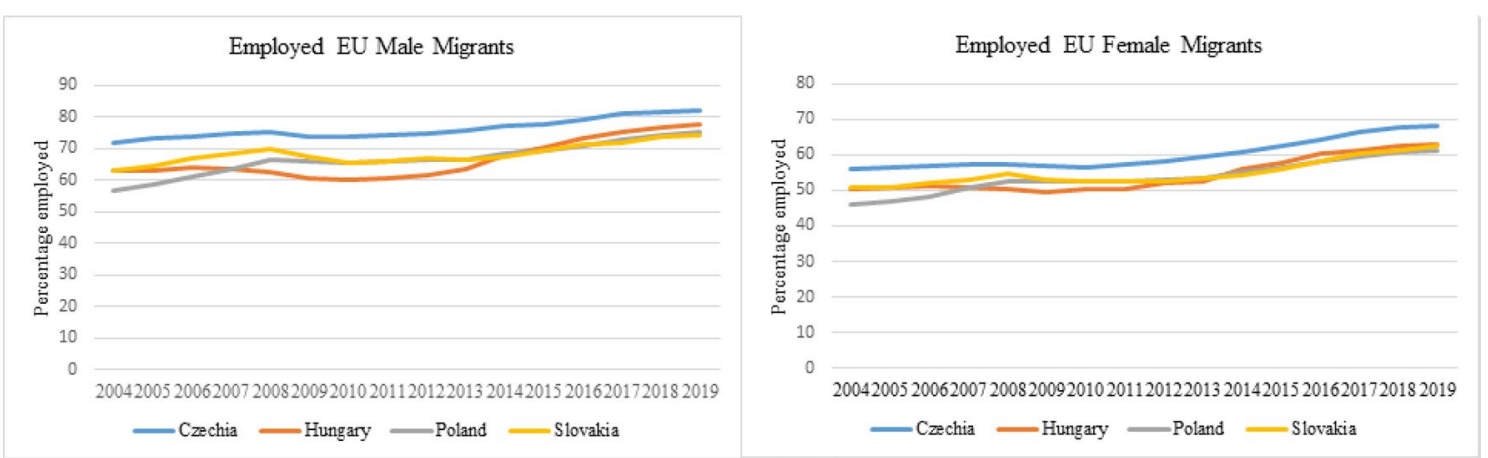

Fig. 5 Employment of EU Labour Except Reporting Country by Gender ( Source: Author's own work using data from EUROSTAT)

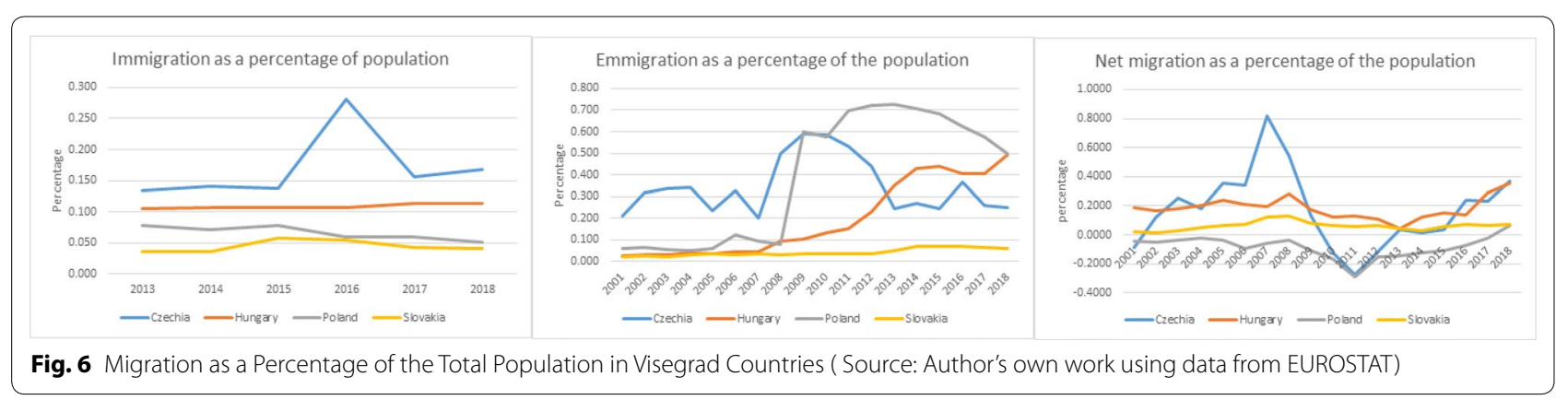


percentage of the total population. For all four Visegrad countries, the percentage of immigrants is less than $1 \%$. The highest percentage is in the Czech Republic, followed by Hungary and Poland. Slovakia has the lowest immigrants to population ratio. The graph for emigrants is more dynamic with cases of emigration to population ratio increasing after the financial crisis, indicating increased labour mobility. Poland overtook the Czech Republic as the country with the highest emigration to population ratio after the crisis. Similarly, Slovakia had an increased emigration to population ratio exceeding that of the Czech Republic. The third part of Fig. 6 shows net migration to population ratio. Before the crisis, the Czech Republic had a fast and positive increasing net migration to population ratio. However, it declined sharply after the crisis to negative. It is now positive and increasing. Net migration to population ratio has been positive and more stable in Hungary and Slovakia. The graph shows that Poland had a negative net migration to population ratio for the most part, implying that more Poles travel outside for work than the other way round. The Czech Republic, Hungary and Slovakia had a positive net migration to population ratio, indicating that more EU migrants travel to these three countries to work. The percentage of net migration is too low, however, at less than $1 \%$, which highlights the low movement of labour across the Visegrad region.
According to the Migration Policy Institute (2020), the percentage of legal immigrants in the US is about $15 \%$ and has been rising since the 1960s. This is a big contrast to the case of the Visegrad countries, where the percentage of immigrants is less than $1 \%$. The Institute also noted that the percentage of immigrant labour in the civil service has been growing since the 1980s and is currently around $20 \%$ of the labour force in the US (Migration Policy Institute 2020). The same cannot be said for the Visegrad countries, where policy restrictions and language barriers make it virtually impossible for immigrant workers to participate in the civil service.

Given the information on labour mobility in Figs. 4, 5 and 6 , the study further investigates the impact of labour mobility on employment using a cointegrated panel ARDL model. A significant and positive coefficient for migration (labour mobility) indicates that labour mobility aids in adjustment to asymmetric shocks and a negative or insignificant coefficient indicates otherwise. The results are for the period before the financial crisis and after the crisis. Table 7 shows the ARDL model for the period before the financial crisis for all four countries. The coefficient for migration (labour mobility) is significant and positive, indicating that labour mobility contributes to the adjustment to asymmetric shocks. The adjustment parameters are negative and statistically significant, indicating long-term convergence to the

Table 7 ARDL model before the financial crisis

\begin{tabular}{|c|c|c|c|c|c|}
\hline Variable & ECT & Czechia & Hungary & Poland & Slovakia \\
\hline \multirow[t]{2}{*}{$E C T$} & & $-0.313^{* *}$ & $-0.189 * * *$ & $-0.200^{* * *}$ & $-0.168^{* * *}$ \\
\hline & & $(0.154)$ & $(0.059)$ & $(0.016)$ & $(0.061)$ \\
\hline \multirow[t]{2}{*}{$\Delta$ Employment $_{t-1}$} & & 0.293 & $0.558^{* * *}$ & $0.671^{* * *}$ & $0.575^{* * *}$ \\
\hline & & $(0.188)$ & (0.199) & $(0.230)$ & $(0.135)$ \\
\hline \multirow{2}{*}{$\Delta$ InTechnology $_{t-1}$} & & 0.176 & -4.097 & 0.645 & 0.445 \\
\hline & & $(2.406)$ & (3.035) & $(1.507)$ & (1.329) \\
\hline \multirow[t]{2}{*}{$\Delta$ InMigration $_{t-1}$} & & 0.009 & 0.013 & $0.076^{* *}$ & $0.012^{*}$ \\
\hline & & $(0.015)$ & $(0.062)$ & $(0.034)$ & $(0.006)$ \\
\hline \multirow[t]{2}{*}{$\Delta$ InRealvalueadded $_{t-1}$} & & $9.498^{* * *}$ & -3.317 & 0.107 & 0.743 \\
\hline & & $(3.627)$ & (3.966) & $(2.368)$ & $(2.785)$ \\
\hline \multirow[t]{2}{*}{ InTechnology } & $8.138^{* * *}$ & & & & \\
\hline & $(0.570)$ & & & & \\
\hline \multirow[t]{2}{*}{ InMigration } & $0.105^{* * *}$ & & & & \\
\hline & $(0.038)$ & & & & \\
\hline \multirow[t]{2}{*}{ InRealvalueadded } & $6.857^{*}$ & & & & \\
\hline & (3.688) & & & & \\
\hline \multirow[t]{2}{*}{ Constant } & & 22.622 & $-14.731^{* * *}$ & -18.302 & $-11.378^{* *}$ \\
\hline & & (16.138) & $(5.470)$ & (11.998) & $(4.860)$ \\
\hline
\end{tabular}

Each variable has a maximum lag set to five. The study determined the optimal lag lengths using the AIC. Standard errors are represented in parentheses, ${ }^{* * *} \mathrm{p}<0.01$, ${ }^{* *} \mathrm{p}<0.05,{ }^{*} \mathrm{p}<0.1, \Delta$ represents first-order difference. $t-1, t-2 . . t-j$ represent lags. $\mathrm{L}$ is used to represent the long run. ECT means error correction term 
Table 8 ARDL Model After Financial Crisis

\begin{tabular}{|c|c|c|c|c|c|}
\hline Variable & ECT & Czechia & Hungary & Poland & Slovakia \\
\hline \multirow[t]{2}{*}{ ECT } & & $-0.158^{* * *}$ & $-0.193^{* * *}$ & $-0.259^{* * *}$ & $-0.215^{* *}$ \\
\hline & & $(0.041)$ & $(0.0103)$ & $(0.224)$ & $(0.0214)$ \\
\hline \multirow[t]{2}{*}{$\Delta$ Employment $_{t-1}$} & & 0.075 & $0.605^{* *}$ & $-0.814^{* * *}$ & 0.584 \\
\hline & & $(0.195)$ & $(0.289)$ & $(0.195)$ & $(0.432)$ \\
\hline \multirow{2}{*}{$\Delta$ InTechnology $y_{t-1}$} & & $-7.649^{* *}$ & $-22.270^{* * *}$ & 4.877 & -4.626 \\
\hline & & (3.888) & $(5.601)$ & $(5.796)$ & $(6.252)$ \\
\hline \multirow[t]{2}{*}{$\Delta \operatorname{lnTechnology} y_{t-2}$} & & 6.208 & $21.774^{* * *}$ & $-9.703^{* *}$ & 6.405 \\
\hline & & $(4.167)$ & $(5.833)$ & $(4.002)$ & (5.794) \\
\hline \multirow{2}{*}{$\Delta \operatorname{lnTechnology} y_{t-3}$} & & -2.146 & $-6.630^{* * *}$ & $3.440^{* * *}$ & -2.039 \\
\hline & & $(1.746)$ & $(2.532)$ & $(1.222)$ & $(2.377)$ \\
\hline \multirow[t]{2}{*}{$\Delta$ InMigration $_{t-1}$} & & -0.000 & -0.072 & 0.052 & 0.005 \\
\hline & & $(0.013)$ & $(0.064)$ & $(0.041)$ & $(0.017)$ \\
\hline \multirow[t]{2}{*}{$\Delta$ InRealvalueadded $t_{t-1}$} & & $9.957^{* * *}$ & 0.339 & $-2.998^{*}$ & 5.256 \\
\hline & & $(2.725)$ & $(5.811)$ & $(1.609)$ & (8.553) \\
\hline \multirow[t]{2}{*}{ InTechnlogy } & $4.603^{* * *}$ & & & & \\
\hline & $(0.2877)$ & & & & \\
\hline \multirow[t]{2}{*}{ InMigration } & $0.186^{* * *}$ & & & & \\
\hline & $(0.020)$ & & & & \\
\hline \multirow[t]{2}{*}{ InRealvalueadded } & $6.195^{* * *}$ & & & & \\
\hline & $(0.486)$ & & & & \\
\hline \multirow[t]{2}{*}{ Constant } & & -0.330 & -0.697 & -16.632 & -1.865 \\
\hline & & $(1.229)$ & $(1.715)$ & $(11.630)$ & $(2.727)$ \\
\hline
\end{tabular}

Each variable has a maximum lag set to five. The study determined the optimal lag lengths using the AIC. Standard errors are represented in parentheses, ${ }^{* * *} \mathrm{p}<0.01$, ${ }^{* *} p<0.05,{ }^{*} p<0.1, \Delta$ represents first order difference. $t-1, t-2 . . t-j$ represent lags. $L$ is used to represent the long run. ECT means error correction term

equilibrium. Furthermore, $31.0 \%$ of deviations in employment is corrected per period in the Czech Republic, $18.9 \%$ in Hungary, $20.0 \%$ in Poland, and $16.8 \%$ in Slovakia. The convergence is slow, however, given the sizes of the speed of adjustment parameters. The size of adjustment coefficients shows that it takes about 3-5 years for the economies to adjust to an asymmetric shock through labour mobility. The fastest speed of adjustment occurs in the Czech Republic. The coefficient for migration or labour mobility is significant and positive, indicating that labour mobility contributes to adjustment to asymmetric shocks.

Table 8 shows the ARDL results for the period after the financial crisis. The speed of adjustment parameters for all the countries is negative and statistically significant, indicating convergence. All the countries converge in the long run but the size of the speed of adjustment parameters shows slow convergence. Moreover, $15.8 \%$ of deviations in employment is corrected per period in the Czech Republic, 19.3\% in Hungary, 25.9\% in Poland, and $21.5 \%$ in Slovakia. The fastest convergence to the equilibrium in Poland is attributed to the higher rate of emigration than the other three countries. The size of the speed of adjustment shows that it takes 4-5 years for countries to adjust to asymmetric shocks through labour mobility. The coefficient of migration (labour mobility) is positive and statistically significant, indicating the positive contribution of labour mobility to adjustment to asymmetric shocks.

Both ARDL models are checked for violation of assumptions, such as autocorrelation, normality and heteroscedasticity. No assumptions were violated. The paper carries out bounds testing to check for long run relationships in the cointegrated panel ARDL models. The observed F statistics from the Wald tests are greater than the upper bound of the bounds test in all the models, indicating the presence of long run relationships among the variables.

\section{Discussion}

This section discusses the results of this paper and compares them with findings of other authors. It covers the results generated from the SVAR models for all the countries before and after the global financial crisis, as well as the results of the ARDL models. One of the key findings of this study is that there were both symmetric and 
asymmetric shocks before and after the global financial crisis. Before the global financial crisis, in the Czech Republic, external supply shocks impacted negatively on real domestic GDP and the price level but positively on the exchange rate. Real domestic supply shocks impacted positively on the exchange rate and the price level. The impact of demand shocks on the price level was positive. After the crisis, a positive shock to the WUI impacted positively on real domestic GDP, the exchange rate and the price level. A positive real domestic supply shock impacted negatively on the exchange rate and the price level. The impact of demand shocks on the price level changed to negative.

Regarding Hungary, there were also differences in responses to shocks before and after the financial crisis. Before the crisis, the impact of external supply shocks on real domestic GDP, the exchange rate and the price level was negative. The impact of real domestic supply shocks on the exchange rate and the price level was negative. The impact of demand shocks on the price level was positive. After the crisis, external supply shocks impacted positively on domestic GDP and the exchange rate but negatively on the price level. The impact of real domestic supply shocks on the exchange rate and the price level remained the same (negative). The impact of demand shocks on the price level changed to negative.

In Poland, before the global financial crisis, the impact of external supply shocks on real domestic GDP and the exchange rate was negative. The impact on the price level was positive. Real domestic supply shocks had a negative impact on the exchange rate and a positive impact on the price level. The impact of demand shocks on the price level was negative. After the crisis, the impact of external supply shocks remained negative on real domestic GDP but positive on the exchange rate and negative on the price level. A shock to real domestic supply impacted negatively on the exchange rate and the price level. The impact of demand shocks on the price level remained negative.

In Slovakia, before the financial crisis, the impact of external supply shocks was positive on domestic GDP and the price level but negative on the exchange rate. The impact of domestic supply shocks was negative on the exchange rate and the price level. The impact of demand shocks was positive on the price level. After the financial crisis, external supply shocks impacted negatively on domestic GDP, the exchange rate and the price level. A shock to real domestic supply impacted negatively on the exchange rate and positively on the price level. The impact of domestic demand shocks on the price level remained positive.

The outcome of the analysis of shocks shows that most shocks were asymmetric before the financial crisis and that the highest correlation occurred with regard to external supply shocks dominated by Hungary. External supply shocks and domestic supply shocks became asymmetric after the global financial crisis. Demand shocks and monetary shocks remained asymmetric. Slovakia had the highest correlation of external supply shocks, Hungary the highest correlation of domestic supply shocks, and Poland the highest correlation of demand shocks. The results also show that there were more changes in the correlation of supply shocks than in demand shocks. For the period before the crisis and after the crisis, there were positive changes in the correlation of supply shocks and negative changes in the correlation of demand shocks. For the Visegrad group, the correlation of demand shocks was lower than that of supply shocks. The weak correlation of demand shocks is explained by the differences in the economic, trade and financial structures of the countries. The positive synchronisation of supply shocks is explained by the process of structural convergence within the Visegrad group through trade integration. The few cases of asymmetric shocks are explained by industrial specialisation across the Visegrad countries, thus making the effect of industry-specific disturbances more likely to be concentrated in single countries, as suggested by De Grauwe and Vanhaverbeke (1991).

The findings align with those of Horvath (2000), who analysed the correlation between demand and supply shocks for the Baltic countries and the Visegrad group. In this case, Hungary was characterised by the highest correlation of aggregate supply shocks and the lowest correlation of aggregate demand shocks. Weimann (2002) found that Bulgaria, the Czech Republic and Hungary registered the strongest correlation of demand shocks. Konopczak and Marczewski (2011) concluded that the response of the economy of Poland to the crisis of 20082009 was different from that of other CEECs owing to the structural characteristics. The findings of this paper correspond to those of Blanchard and Quah (1989), who found that for the EU countries, there are more asymmetric shocks than for US regions.

Frenkel and Nickel (2002) concluded that there are still differences in shocks and adjustment processes between the euro area and many CEECs. Arfa (2009) found that several new member countries of the EU had high correlation of demand shocks with the euro area while supply shocks were asymmetric. Socol and Soviani (2010) and Socol and Măntescu (2011) attributed the weak correlation of demand shocks to differences in national fiscal policies. The existence of asymmetric shocks in the Visegrad region is accounted for by a variety of factors. The higher percentage of the asymmetries observed is attributed to political and governmental factors, for 
example, the differences in the political cycle, fiscal policies and legal systems.

Regarding the question of whether labour mobility helped in the adjustment to asymmetric shocks in the Visegrad region, the results show that the share of labour mobility in the four countries was low. This was measured using the percentage of net migration to total population in each country. The value was less than $1 \%$. The results from the ARDL models before and after the financial crisis show that migration has a positive impact on employment in the Visegrad region. However, the adjustment from migration or labour mobility was slow due to the small size of the speed of adjustment obtained for each of the countries. The size of the speed of adjustment suggests that a shock is absorbed in 3-5 years, which is similar to the results of Decressin and Fatás (1995), who concluded that a significant proportion of the shock is absorbed through labour migration after four years.

Furthermore, the results of this paper are similar to those of Pelagidis (1996), who showed that migration within the EU as a percentage of total population was less than $1 \%$ on average. The results also correspond with those of Martin and Taylor (1996), Obstfeld and Peri (1998) and Piracha and Vickerman (2002), who concluded that labour mobility as a share of total population was lower in European countries than in the US. De Grauwe and Vanhaverbeke (1991) studied labour mobility across several Western European countries and concluded that the annual flow of migrants was less at the national level than interregional migration. The findings above suggest that labour mobility in Visegrad countries is too low to act as an efficient adjustment mechanism to asymmetric shocks. However, as concluded by Puhani (1999), if the cause of the low labour mobility stems from the fact that there are not enough economic incentives to migrate, the above conclusion might change if the obstacles or challenges and incentives are given policy consideration.

\section{Conclusion}

This paper investigates the nature and correlation of shocks among the Czech Republic, Hungary, Poland and Slovakia. It also explains the role of labour mobility in the adjustment to asymmetric shocks among the countries that form a regional economic and political bloc called Visegrad. The paper applies a SVAR model to explain the nature and correlation of shocks. Cointegrated panel ARDL models are employed to assess the role of labour mobility in the adjustment process. The results show that all shocks were asymmetric in the period before the global financial crisis, with a few symmetries occurring in external supply shocks and domestic supply shocks. The results also show that there were more symmetric external supply and domestic supply shocks after the global financial crisis in the four Visegrad countries. Demand and monetary shocks remained asymmetric in the region even after the financial crisis.

Moreover, the results show that the highest correlation of shocks occurred with regard to external supply shocks dominated by Hungary. External supply shocks and domestic supply shocks became asymmetric after the global financial crisis. Demand shocks and monetary shocks remained asymmetric after the crisis. Slovakia had the highest correlation of external supply shocks, Hungary the highest correlation of domestic supply shocks, and Poland the highest correlation of demand shocks. In addition, the results show that there were more changes in the correlation of supply shocks than the correlation of demand shocks. For the period before the crisis and after the crisis, there were positive changes in the correlation of supply shocks and negative changes in the correlation of demand shocks.

The results of this paper also show that labour mobility helps in the process of adjustment to asymmetric shocks in the region, as the coefficient for migration in the models is positive, indicating a positive impact. However, the size of the adjustment coefficients indicates that the countries converged after asymmetric shocks but in a very slow process. Even though there was high employment of migrant labour in the region ranging between 60 and $70 \%$, the total number of migrants in the region was low compared to the total population (less than 1\%). The number of migrants in the US was higher than in the Visegrad region.

Furthermore, there was high participation of migrant workers in the civil service in the US but not in the Visegrad countries. These and other factors contribute significantly to the slow process of adjustment to asymmetric shocks in terms of labour mobility. Plausibly, low labour mobility points partly to the fact that the costs of large-scale labour movement in Visegrad countries are greater than the benefits in the areas of migration. Other obstacles include the non-transferability of pension rights, the restrictions on the right to social security, and nationality restrictions with respect to recruitment in the civil service. There are other issues such as non-recognition of qualifications from member states and asymmetry of information with regard to jobs in other member countries. The consequence is that the role of labour mobility as an adjustment mechanism to asymmetric shocks might improve through policies but the change will be marginal and gradual in the Visegrad countries. Given the obvious picture of an ageing population across the Visegrad region, migration is a force that if given the necessary attention, will play a significant role in the economies of these four countries. 


\section{Acknowledgements \\ Not applicable.}

\section{Authors' contributions}

I wrote the entire paper. I also read it through before approving it for submission. The author read and approved the final manuscript.

\section{Funding}

Not applicable.

\section{Availability of data and materials}

The data for the paper is available through the following weblinks: https:// ec.europa.eu/eurostat/data/database and https://data.oecd.org/.

\section{Competing interests}

The author declares no competing interests.

Received: 13 June 2020 Accepted: 19 October 2020

Published online: 19 November 2020

\section{References}

Ahir, H., Bloom, N., Furceri, D.: The world uncertainty index. International Monetary Fund, Working Paper No. 19-027. https://www.imf.org/external/ pubs/ft/fandd/2020/03/imf-launches-world-uncertainty-index-wui-furce ri.htm(2019). Accessed 15 Febr 2020

Akaike, H.: A new look at the statistical model identification. IEEE Trans. Automat. Contr. 19(6), 716-723 (1974)

Amisano, G., Giannini, C.: Topics in structural var econometrics, 2nd edn. Springer, Berlin (1997)

Arfa, B.N.: Analysis of shocks affecting Europe: EMU and some Central and Eastern acceding countries. Panoeconomicus. 56(1), 1-15 (2009)

Arpaia, A., Kiss, A., Palvolgyi, B., Turrini, S.: Labour mobility and labour market adjustment in the EU. KC-Al-14-539-EN-N. No 396, Development Working Papers from Centro Studi Luca d'Agliano, University of Milan. https:// www.dagliano.unimi.it/media/WP2016_396.pdf (2016). Accessed 4 Apr 2020.

Baltagi, B.H., Griffin, J.M.: Pooled estimators vs their heterogeneous counterparts in the context of dynamic demand for gasoline. J. Econ. 77(2), 303-327 (1997)

Barslund, M., Busse, M.: Making the most of EU labour mobility. Report of a CEPS Task Force in cooperation with the Bertelsmann Stiftung. https:// www.ceps.eu/ceps-publications/making-most-eu-labour-mobility (2014). Accessed 10 Mar 2020.

Baxter, M., Kouparitsas, M.: Determinants of business cycle comovement: a robust analysis. NBER Working Paper, No.10725. https://www.nber.org/ papers/w10725.pdf (2004). Accessed 4 Apr 2020.

Bayoumi, T., Eichengreen, B.: Shocking aspects of European monetary integration. In: Torres, F., Giavazzi, F. (eds.) Adjustment and Growth in the European Monetary Union, 193-230. Cambridge University Press, New York (1993)

Bayoumi, T., Eichengreen, B.: Aftershocks of monetary unification: hysteresis with a financial twist. CEPR Discussion Papers 11850, CEPR Discussion Papers. https://cepr.org/active/publications/discussion_papers/ dp.php?dpno=11850 (2017). Accessed 21 Febr 2020.

Beck, K.: Structural similarity as a determinant of business cycles synchronization in the European Union: a robust analysis. Res. Econ. Busi. 5, 2 (2014)

Bernardi, F., Garrido, L.: Is there a new service proletariat? Post-industrial employment growth and social inequality in Spain. Eur. Sociol. Rev. 24(3), 299-313 (2008)

Beyer, R.C.M., Smets, F.: Labour market adjustments and migration in Europe and the United States: how different? Econ. Policy 30(84), 643-682 (2015)

Blanchard, O., Katz, L.F.: Regional evolutions. Brook. Papers Econ. Act. 23(1), $1-75$ (1992)

Blanchard, O., Quah, D.: The dynamic effects of aggregate demand and supply disturbances. Am. Econ. Rev. 79(4), 655-673 (1989)

Campos, N.F., Macchiarelli, C.: Core and periphery in the European Monetary Union: Bayoumi and Eichengreen 25 years later. Econ. Lett. 147, 127-130 (2016)

Chow, G.C.: Tests of equality between sets of coefficients in two linear regressions. Econometrica. 28(3), 591-605 (1960)
Clarida, R., Gali, J: Sources of real exchange rate fluctuations: how important are nominal shocks? Accessed 4 Apr $2020<$ https://www.nber.org/paper s/w4658.pdf (1994).

Dao, M. D., Furceri, D., Loungani, P.: Regional labour market adjustments in the United States and Europe, IMF Working Paper 2014/26. https://www. imf.org/external/pubs/ft/wp/2014/wp14211.pdf (2014). Accessed 4 Apr 2020.

Decressin, J., Fatás, A.: Regional labour market dynamics in Europe. Eur. Econ. Rev. 39(9), 1627-1655 (1995)

De Grauwe, P.: The Economics of Monetary Union, 6th edn. Oxford University Press, Oxford (2005)

De Grauwe, P., Vanhaverbeke, W.: Is Europe an optimum currency area? Evidence from regional data. Discussion paper, No. 555. cepr.org/active/ publications/discussion_papers/dp.php?dpno=555 (1991). Accessed 4 Apr 2020.

Dickey, D.A., Fuller, W.A.: Distribution of the estimators for autoregressive time series with a unit root. J. Am. Stat. Assoc. 74(366), 427-431 (1979)

European Commission. Adjustment via migration. Quarterly Report on the Euro Area. 10(3), 32-33 (2011).

Eurostat:: Your key to European statistics. https://ec.europa.eu/eurostat/data/ database (2020). Accessed 13 Mar 2020.

Fidrmuc, J., Korhonen, I.: The euro goes east: implications of the 2000-2002 economic slowdown for synchronisation of business cycles between the euro area and CEECs. Comp. Econ. Stud. 46, 45-62 (2004)

Frankel, J., Rose, A.: The endogeneity of the optimum currency area criteria. NBER Working Papers, No. 5700, 1-33 (1996).

Frenkel, M., Nickel, C.: How symmetric are the shocks and the shock adjustment dynamics between the euro area and Central and Eastern European countries? IMF Working Paper, WP/02/222. https://www.imf. org/en/Publications/WP/Issues/2016/12/30/How-Symmetric-Are-theShocks-and-the-Shock-Adjustment-Dynamics-Between-the-Euro-Areaand-16205(2002). Accessed 4 Apr 2020.

Goos, M., Manning, A., Salomons, A.: Explaining job polarization: routine-biased technological change and offshoring. Am. Econ. Rev. 104(8), 2509-2526 (2014)

Hannan, E.J., Quinn, B.G.: The determination of the order of an autoregression. J. R. Stat. Soc. 41(2), 190-195 (1979)

Hauser, D.: Technology shocks, labour mobility and aggregate fluctuations. https://www.econstor.eu/handle/10419/95704 (2014). Accessed 5 Febr 2020.

Hausman, J.A.: Specification tests in econometrics. Econometrica. 46(6), 1251-1271 (1978)

Horvath, J.: Supply and demand shocks in Europe: large-4 EU members, Visegrad-5 and Baltic-3 countries. mimeo. Central European University (2000).

Janus, J., Beck, K.: Synchronization of economic shocks in the visegrad group: an empirical assessment. Studia Universitatis Babes Bolyai-Negotia, 35-56 (2014). https://www.semanticscholar.org/paper/synchronization-ofeconomic-shocks-in-the-Visegrad-Beck-Janus/279421cd4101e921725f 8daea3c017898ac4948b. Accessed 4 Apr 2020.

Johansen, S.: Statistical analysis of cointegration vectors. J. Econ. Dyn. Control 12(2-3), 231-254 (1988)

Kao, C.: Spurious regression and residual-based tests for cointegration in panel data. J. Econ. 90(1), 1-44 (1999)

Kendall, M.G., Stuart, A.: The advanced theory of statistics, vol2, 3rd edn. Hafner New York (1973)

Kenen, P.: The theory of optimum currency areas: an eclectic view. In: Mundell, R., Swoboda, A. (eds.) Monetary Problems in the International Economy, 41-60. University of Chicago Press, Chicago (1969)

Konopczak, K., Marczewski, K.: Why so different from other CEECs - Poland's cyclical divergence from the euro area during the recent financial crisis. Bank i Kredyt 41(2), 7-30 (2011)

Krugman, P.: Lessons of Massachusetts for EMU. In: Torres, F., Giavazzi, F. (eds.) Adjustment and growth in the European Monetary Union, pp. 241-261. Cambridge University Press, Cambridge (1993)

L'Angevin, C.: Labour market adjustment dynamics and labour mobility within the euro area. Documents de Travail de la DGTPE No. 06. https://www. tresor.economie.gouv.fr/Articles/96a4dae9-42be-449c-af42-12d233d3ba fd/files/cb2ab482-65bc-4d56-a57a-47a1 c1 c6f994 (2007). Accessed 4 Apr 2020.

Lee, G., Azali, M.: The endogeneity of the optimum currency area criteria in East Asia. Econ. Model. 27(1), 165-170 (2010) 
Lehwald, S.: Has the euro changed business cycle synchronization? Evidence from the core and the periphery. IFO Working Papers, No. 122. https:// www.ifo.de/DocDL/lfoWorkingPaper-122.pdf (2012). Accessed 17 Jan 2020.

Levin, A., Lin, C.-F.: Unit root test in panel data: asymptotic and finite sample properties. Discussion Paper No: 92-93, University of California at San Diego (1992)

Lütkepohl, H.: New Introduction to Multiple Time Series Analysis. Springer, New York (2005)

Martin, P. L., Taylor, J. E.: The anatomy of a migration hump, in J. Edward Taylor, ed., Development Strategy, Employment, and Migration: Insights from Models. Paris: Organization for Economic Cooperation and Development, 43-62(1996).

Mayda, A.M.: Who is against immigration? A cross-country investigation of individual attitudes toward immigrants. Rev. Econ. Stat. 88(3), 510-530 (2006)

McKinnon, R.: Optimum currency areas. Am. Econ. Rev. 53(4), 717-725 (1963)

Migration Policy Institute: Migration Data Hub. https://www.migrationpolicy .org/. 2020. Accessed 4 Apr 2020.

Mundell, R.: A theory of optimum currency areas. Am. Econ. Rev. 51(4), 657-665 (1961)

Nchor, D., Rozmahel, P.: Job polarisation in Europe: evidence from Central and Eastern European countries. Danube: Law, Economics and Social Issues Review. 1(2020), 1-23 (2020).

Ngai, L.R., Pissarides, C.A.: Structural change in a multisector model of growth. Am. Econ. Rev. 97(1), 429-443 (2007)

Obstfeld, M., Peri, G.: Regional non-adjustment and fiscal policy. Econ. Policy. 13(26), 206-259 (1998)

OECD.: OECD economic surveys: European Union. OECD. https://www.oecdilibrary.org/economics/oecd-economic-surveys-european-union-2012 eco_surveys-eur-2012-en\#: :text=OECD's\%202012\%20Economic\%20Sur vey\%20of,market\%2C\%20and\%20mobilit (2012). Accessed 4 Apr 2020.

Oesch, D., Rodriguez, M.J.: Upgrading or polarization? Occupational change in Britain, Germany, Spain and Switzerland, 1990-2008. Socio-Econ. Rev. 9(3), 1-32 (2011)

Pelagidis, T.: Optimum currency area approach and the third stage of EMU: a review of recent evidence. Rivista Internazionale di Scienze Economiche e Commerciali. 43(4), 759-789 (1996)

Pesaran, M.H., Shin, Y., Smith, R.P.: Pooled mean group estimation of dynamic heterogeneous panels. J. Am. Stat. Assoc. 94(1999), 621-634 (1999)

Piracha, M., Vickerman, R.: International migration and European integration. Paper presented at the 40th Annual Meeting, Western Regional Science
Association, Palm Springs, CA, February, Department of Economics, University of Kent. https://citeseerx.ist.psu.edu/viewdoc/download?doi=10.1 .1.196.8546\&rep=rep1\&type =pdf (2002). Accessed 4 Apr 2020.

Puhani, P, A.: Labour mobility - an adjustment mechanism in Euroland? Empirical evidence for Western Germany, France, and Italy. Ger. Econ. Rev, 2(2), 127-140(1999).

Rand, J., Tarp, F.: Business cycles in developing countries: are they different? University library of Munich, Germany. MPRA Paper 62445. https://mpra. ub.uni-muenchen.de/62445/1/MPRA_paper_62445.pdf(2001). Accessed 4 April 2020.

Sachs, A., Schleer, F.: Labour market institutions and structural reforms: a source for business cycle synchronization? J. Appl. Econ 10(1), 63-83 (2013)

Saks, R., Wozniak, A.: Labour reallocation over the business cycle: new evidence from internal migration. Labour Econ. 29(4), 697-739 (2011)

Schwarz, G.: Estimating the dimension of a model. Ann. Stat. 6(2), 461-464 (1978)

Silvestre, J., Mendonca, A., Passos, J.: The shrinking endogeneity of optimum currency areas criteria: evidence from the European Monetary Union - a beta regression approach. ISEG Working Papers, No. 22. https://depec o.iseg.ulisboa.pt/wp/wp222007.pdf (2009). Accessed 20 Jan 2020.

Socol, A.G., Măntescu, D.: Re-modeling the Romanian fiscal policy under the terms of the economic crisis. Theor. Appl. Econ. 1(554), 111-120 (2011)

Socol, C., Soviani, R.: Experiences of the large fiscal adjustments in EU Romania's case. Theor. Appl. Econ. 12(553), 21-28 (2010)

UNCTAD. Data Center. https://unctadstat.unctad.org/wds/ReportFolders/ reportFolders.aspx (2020). Accessed 8 March 2020.

Weimann, M.: OCA theory and EMU Eastern enlargement-an empirical application. Dresdner Beiträge zur Volkswirtschaftslehre. 7, 5-30 (2002)

Yue, S., Pilon, P.J., Phinney, B., Cavadias, G.: The influence of autocorrelation on the ability to detect trend in hydrological series. Hydrol. Process. 16(9), 1807-1829 (2002)

\section{Publisher's Note}

Springer Nature remains neutral with regard to jurisdictional claims in published maps and institutional affiliations.

\section{Submit your manuscript to a SpringerOpen ${ }^{\circ}$ journal and benefit from:}

- Convenient online submission

- Rigorous peer review

- Open access: articles freely available online

- High visibility within the field

- Retaining the copyright to your article

Submit your next manuscript at $\boldsymbol{\nabla}$ springeropen.com 